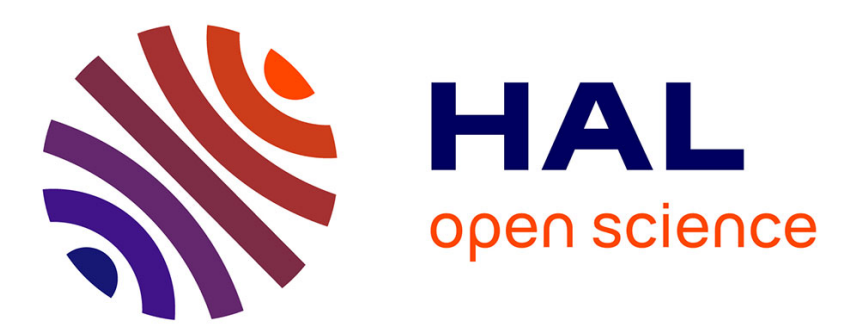

\title{
Phase assemblage of a 5 year-old cement paste after submission to various high temperature and cooling regime.
}

\author{
Mickael Saillio, Hassen Sabeur, Julien Vincent, Bruno Zitoun
}

\section{To cite this version:}

Mickael Saillio, Hassen Sabeur, Julien Vincent, Bruno Zitoun. Phase assemblage of a 5 year-old cement paste after submission to various high temperature and cooling regime.. Construction and Building Materials, 2021, 279, pp.122440. 10.1016/j.conbuildmat.2021.122440 . hal-03136043

\section{HAL Id: hal-03136043 \\ https://hal.science/hal-03136043}

Submitted on 9 Feb 2021

HAL is a multi-disciplinary open access archive for the deposit and dissemination of scientific research documents, whether they are published or not. The documents may come from teaching and research institutions in France or abroad, or from public or private research centers.
L'archive ouverte pluridisciplinaire HAL, est destinée au dépôt et à la diffusion de documents scientifiques de niveau recherche, publiés ou non, émanant des établissements d'enseignement et de recherche français ou étrangers, des laboratoires publics ou privés. 


\title{
Phase assemblage of a 5 year-old cement paste after submission to various high temperature and cooling regime
}

\author{
Mickael SAILLIO $^{\mathrm{a}^{*}}$, Hassen SABEUR ${ }^{\mathrm{b}, \mathrm{c}}$, Julien VINCENT ${ }^{\mathrm{a}}$, Bruno ZITOUN ${ }^{\mathrm{a}}$ \\ ${ }^{a}$ MAST-CPDM, Gustave Eiffel University, F-77454 Marne-La-Vallée, France \\ ${ }^{b}$ Tunisia Polytechnic School, Archaeological Site of Carthage 2078 Tunis, Tunisia. \\ ${ }^{C}$ Laboratory of Civil Engineering, Le Belvédère 1002 Tunis, Tunisia.
}

\begin{abstract}
In case of fire in a structure, concrete undergoes internal transformations that can alter its durability. It is also important to take into account the effect of the cooling regime after temperature exposure on the phase assemblage of the cementitious matrix. An experimental investigation was carried out to investigate the changes of a cement paste, heated up to various temperature up to $1000^{\circ} \mathrm{C}$ then cooled in water or cooled in air for comparison. Quantitative evolution of phase assemblage is obtained by various techniques (TGA, XRD, NMR and ICP-AES).
\end{abstract}

For both cooling regimes, the hydrated crystallised phases tend to become disordered phases for lower exposition temperature. These phases coexist with anhydrous products for intermediate temperature and these new anhydrous phases become the majority for higher temperature. However, the two cooling regimes show differences. Equilibrium of hydrated aluminate phases is modified, (e.g. AFm/AFt ratio). There are structural modifications of the phases in particular for $C-S$ - $H$. For water cooling regime, beyond $600^{\circ} \mathrm{C}$, a leaching is observed in particular for calcium.

*Corresponding author. Tel.: +33181668734

E-mail address: mickael.saillio@ifsttar.fr

Keywords: high temperature, water- cooling regime, cement paste, TGA, XRD, NMR

\section{Introduction}

The behaviour of concrete exposed to fire is a subject of great interest, especially after the fires which ravaged Australia causing significant material damage in addition to the losses of human lives.

Indeed, durability of concrete structure exposed to such accidental conditions is an important issue in case we need to decide whether to replace the damaged part or to let it in place safely. An important reduction in the compressive strength of concrete exposed to temperatures beyond $500^{\circ} \mathrm{C}$ is noticed and beyond $900^{\circ} \mathrm{C}$ at the core, the concrete can be fully deteriorated [1-5]. In fact, there is modification of concrete when it heated at high temperature. The same is observed for aggregates (e.g. cracks in siliceous aggregates above $570^{\circ} \mathrm{C}$ ) and also, in particular, for the cementitious matrix. The behaviour of a cement paste at high temperature is the result of many factors; particularly achieved temperature, exposure time and cooling regimes. Much literature has dealt with the influence of different heating rates and the effects of cooling regimes on the behaviors of cement paste at high temperatures [1-8].

Considering the evolution of the phase assemblage after exposure at high temperature, the dehydroxylation reaction of portlandite is reversible [1,7], but this new portlandite is an onset temperature of decomposition lower than the original portlandite and its structure appears less crystalline [4]. In addition, the ettringite is destroyed above $80^{\circ} \mathrm{C}$ and the $\mathrm{C}-\mathrm{S}-\mathrm{H}$ is gradually dehydrated with a crystalline modification at around $400^{\circ} \mathrm{C}$. As for portlandite, dehydrated C-S-H products got rehydrated after being re-cured in the environment with sufficient moisture [2-4]. It seems that the rehydrated structure got denser with the increase of exposed temperature. Finally, the larnite and the brownmillerite (anhydrous phases) are present in all heated specimens

All these studies have been published on the changes in the microstructure of hydrated Portland cement, ranging from changes in the mineralogy to changes in pore structure. In addition, their tests 
were done generally at 28 days after demoulding and the maximum temperature reached while conducting these researches was $800^{\circ} \mathrm{C}$. However, in a real fire, this temperature of $800^{\circ} \mathrm{C}$ is reached in about 20 minutes (ISO fire curve) while a fire could continue for hours and the concrete is more often aged. In fact, during fire, a profile of temperature from surface to deep inside is observed. Overall, there is no information on the microstructural changes of aged cement paste submitted to high temperatures and to various water-cooling regime and this is the goal of the present study.

This research work is a continuation of previous papers [9-11] dealing with the effect of cooling regime (at the desiccator or in ambient air with relative humidity) on the microstructure evolution of aged cement pastes. The present study highlights the thermal effects on the mineralogical properties as well as the microstructure of 5 year old cement pastes by studying phase assemblage obtained by TGA/DTA, XRD, ${ }^{27} \mathrm{Al}$ MAS NMR and ${ }^{29} \mathrm{Si}$ MAS NMR, where the maximum reached temperature is $1000^{\circ} \mathrm{C}$ and with water cooling regime (comparison with air cooling regime). This work was done in order to simulate the state of samples in the situation of a fire where water spraying is usually used for fire extinguishing and consequently thermal shock is induced to the concrete.

\section{Experimental}

\subsection{Materials}

The samples are cement paste, 5 years old. The cement paste was made with a water/cement ratio of 0.272 with an ordinary Portland cement CEM I. The cement paste cylinders ( $30 \mathrm{~mm}$ diameter and 30 $\mathrm{mm}$ height) were cured for 28 days into plastic waterproof bags in a room at $22 \pm 2^{\circ} \mathrm{C}$. The main constituents of cement are listed in Table1.

Table 1: Chemical composition of the cement tested (in \%mass) obtained by ICP-AES.

\begin{tabular}{|l|l|}
\hline \multicolumn{2}{|l|}{ Oxide constituent /\% } \\
\hline $\mathrm{SiO}_{2}$ & 20.5 \\
\hline $\mathrm{Al}_{2} \mathrm{O}_{3}$ & 5.1 \\
\hline $\mathrm{Fe}_{2} \mathrm{O}_{3}$ & 3.7 \\
\hline $\mathrm{CaO}$ & 64.0 \\
\hline $\mathrm{MgO}$ & 1.3 \\
\hline $\mathrm{K}_{2} \mathrm{O}$ & 0.5 \\
\hline $\mathrm{Na}_{2} \mathrm{O}$ & 0.4 \\
\hline $\mathrm{SO}_{3}$ & 2.0 \\
\hline $\mathrm{CO}_{2}$ & 2.0 \\
\hline $\mathrm{Chloride}$ & 0.0 \\
\hline $\mathrm{IR}$ & 0.6 \\
\hline $\mathrm{CaOL}$ & 0.4 \\
\hline
\end{tabular}

Table 2: Mean characteristics of the cement CEM I 42.5 (in \%mass).

\begin{tabular}{|l|l|l|l|}
\hline \multicolumn{2}{|l|}{ Mineral Composition /\% } & \multicolumn{2}{l|}{ Main components/\% } \\
\hline $\mathrm{C}_{3} \mathrm{~S}$ & $52.8-63.0$ & Clinker & $90-95$ \\
\hline $\mathrm{C}_{2} \mathrm{~S}$ & $7.8-17$ & Calcareous & $\leq 5$ \\
\hline $\mathrm{C}_{3} \mathrm{~A}$ & $5-12$ & Gypsum & 3 \\
\hline $\mathrm{C}_{4} \mathrm{~A} \mathrm{~F}$ & $8-14$ & & \\
\hline
\end{tabular}

\subsection{Heating process}

The 5 year-aged cement paste, unprotected from contact with the air, were heated in PROLABO Volca MC 25 furnace at a heating rate of $20^{\circ} \mathrm{C} / \mathrm{min}$, in steps of $100^{\circ} \mathrm{C}$, maintained 6 hours up to $1000^{\circ} \mathrm{C}$. The heating rate is lower than the ISO 834, but previous studies indicated that the results are so comparable [12-14]. The heating treatment is denoted HT. 


\subsection{Cooling process}

A part of the materials was air-cooling (denoted AC) and another part was water cooled (denoted WC). For this last, the hot blocks of cement paste at the temperature plateau were taken out of the furnace and immediately immersed in a freshwater tank with water temperature at $20 \pm 2{ }^{\circ} \mathrm{C}$, during 12 hours. This water-cooling regime represents the real case where water spraying is usually used for fire extinguishing and consequently thermal shock is induced to the concrete. The experimental results of other authors indicated that, compared with natural cooling by air, thermal shock induced by water quenching and spraying water caused more severe damage to concrete, in terms of greater losses in compressive strength, tensile splitting strength, and fracture energy [12]. In addition, the solution which served for cooling was analyzed by ICP-AES (elementary analysis) in order to quantify elements which could be lost during WC (leaching effect).

Afterward, the materials were placed in a desiccator for another 24 hours in order to allow the watersoaked specimens to dry superficially; which is the most representative of the real situation and facilitates also the crushing step. The amount of material to be subjected to microstructural tests was crushed and ground until reaching a grain size of $80 \mu \mathrm{m}$.

\subsection{Microstructural characterization}

The apparatus used in the thermo-gravimetric studies is a NETZSCH STA 409 [1] by heating from $25^{\circ} \mathrm{C}$ to $1150^{\circ} \mathrm{C}$ with a $25^{\circ} \mathrm{C} / \mathrm{min}$ ramp.

The XRD analyses were performed using the PHILIPS PW3830 diffractometer [15] with the Ka radiation of cobalt $(40 \mathrm{KV}$ and $30 \mathrm{~mA})$. The scan step size of the diffractometer was $0.02 \% \mathrm{~s}$ in the range of $2 \Theta$ from 4 and $76^{\circ}$.

NMR spectra have been obtained with a Bruker Avance $500 \mathrm{MHz}$ apparatus (11.74 T magnetic field) [3], [16-18]. For ${ }^{27} \mathrm{Al} \mathrm{NMR,} \mathrm{parameters} \mathrm{were:} \pi / 6$ pulses (to allow quantitative analysis), $14 \mathrm{kHz}$ spinning speed, 280 scans and $10 \mathrm{~s}$ repetition time. For ${ }^{29} \mathrm{Si}$ NMR, parameters were: $\pi / 2,5 \mathrm{kHz}$ spinning speed, 1008 scans and 50s repetition time. ${ }^{27} \mathrm{Al}$ and ${ }^{29} \mathrm{Si}$ nuclei were probed here by the one-pulse MAS (Magical Angle Spinning) technique. More details concerning the experimental procedure are available in references [9-11]. Due to the high number of samples, a selection of ${ }^{29} \mathrm{Si}$ MAS NMR experiments on sample has been made and this study focuses on samples exposed to 6 temperatures $\left(25^{\circ} \mathrm{C}, 100^{\circ} \mathrm{C}, 400^{\circ} \mathrm{C}, 600^{\circ} \mathrm{C}, 800^{\circ} \mathrm{C}\right.$ and $\left.1000^{\circ} \mathrm{C}\right)$.

\subsection{Method used to quantify each phase of the cementitious matrix and complementary calculations}

The method used to quantify each phase from a combination of MAS NMR spectroscopy, elementary analysis by ICP-AES and TGA/DTA is fully described in [19] and will not be reproduced here. It will denoted as "combined technique" in the legend of the figures. In addition, lime appeared on the diffractogramms for samples at temperature higher than $600^{\circ} \mathrm{C}$. Consequently, for the sample exposed at these temperatures, lime amount was also calculated by difference of the calcium total amount with the sum of all the other phases containing calcium, assuming $\mathrm{C} / \mathrm{S}=1.5$ of the $\mathrm{C}-\mathrm{S}-\mathrm{H}$ (which is the value of the sample at $25^{\circ} \mathrm{C}$ ). This ratio was also found in [3] for temperature superior to $450^{\circ} \mathrm{C}$.

In this work, it is important to understand there are two effects on samples. There is the effect of the heating treatment (HT) and then the effect of the cooling regime in the air (AC) or in the water (WC). Characterizations were made only after each cooling regime in addition to reference sample (before heating). Consequently, the results on temperature effect with $\mathrm{AC}$ are presented first, which is the simplest case and then the comparison between AC and WC.

\section{Results and discussion}

\subsection{Temperature effect with air cooling regime (AC)}



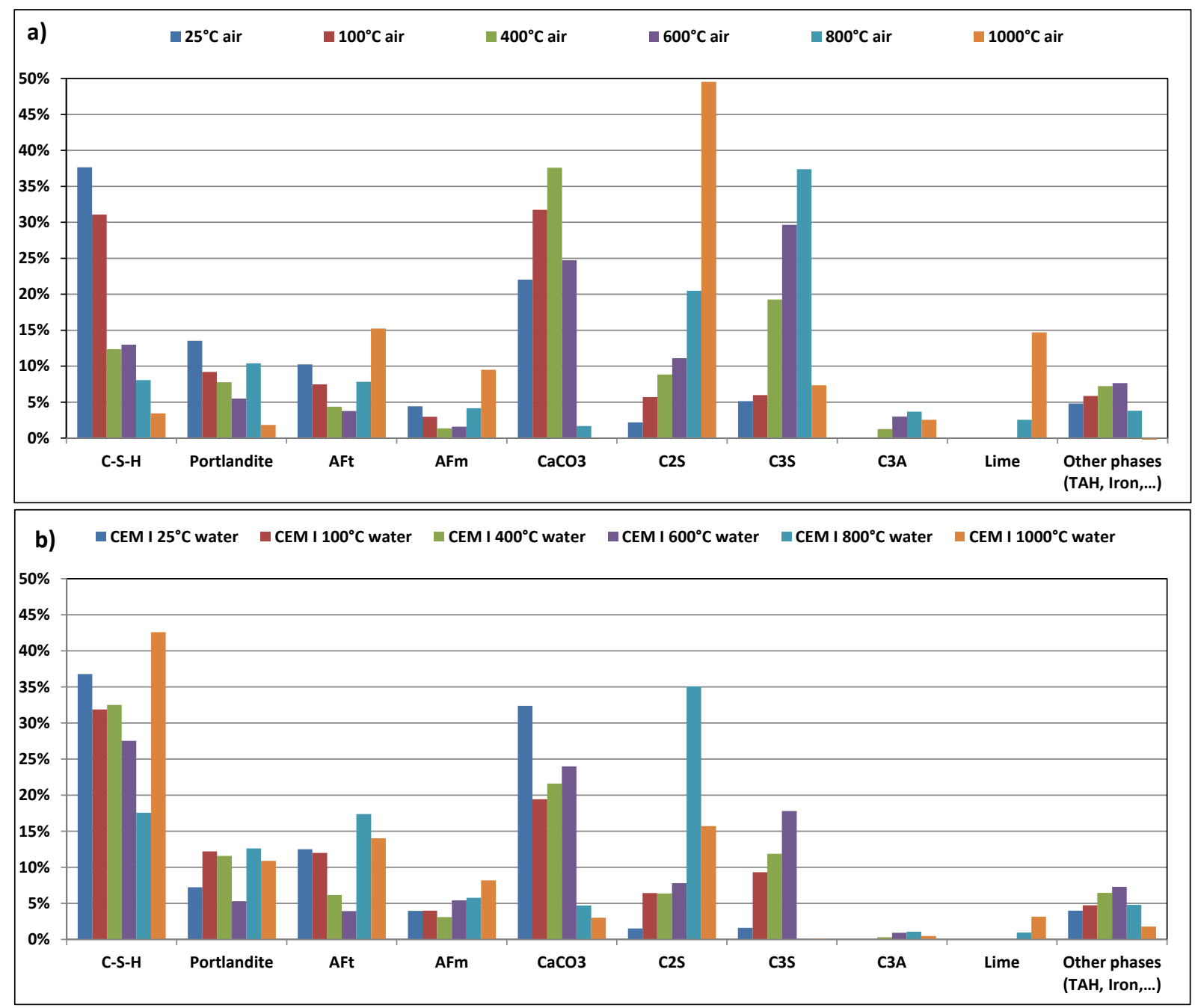

Figure 1: Comparisons of mass proportion of cement paste exposed at various temperatures and the same air or water cooling regime. Results are obtained by combined technique [19]. Here C-S-H= C-S-H+silica gel, $\mathrm{AFt}=$ Ettringite and $\mathrm{AFm}=$ Monocarboaluminate, Hemicarboaluminate and Monosulfoaluminate.

The combined technique gives access to the phases assemblage of a cementitious material after heat treatment (HT) followed by air cooling (AC) (see figure 1a). Other additional information can also be obtained from the XRD and DTG, in particular to identify some phases such as monocarboaluminates or crystalline type of calcium carbonates such as calcite (see figure $2 \mathrm{a}$ and $2 \mathrm{~b}$ and see figure $3 \mathrm{a}$ and $3 b)$.

Temperature increase has a strong impact on the phase assemblage as expected [1-8]. In general observations, hydrated phases and calcium carbonate decrease when both anhydrous phases $\left(\mathrm{C}_{2} \mathrm{~S}, \mathrm{C}_{3} \mathrm{~S}\right.$ and $\left.\mathrm{C}_{3} \mathrm{~A}\right)$ and lime $(\mathrm{CaO})$ increase. The hydrated phases do not disappear completely but a minima value is obtained and some phases appear after $600^{\circ} \mathrm{C}$ in higher quantities. In the present work, it has deliberately been chosen to allow the samples to cool in an ambient atmosphere for at least 24 hours, before making the characterizations. Consequently, the pieces seem to capture the relative humidity of the air during cooling and then, they can obviously reform some hydrated phases (AFt and AFm phases). In addition, lime appears, according to $\mathrm{XRD}$, from the temperature of $500^{\circ} \mathrm{C}$. This phase seems to be very reactive in the presence of water and it can contribute to form hydrates and in particular ettringite in presence of $\mathrm{SO}_{3}$. TGA and XRD were performed few hours just after the cooling time. However, for experimental reasons linked to the NMR technique (handling time and availability of the apparatus), these characterizations were made few days after cooling. The samples were stored in sealed bottles but it was preferred not to apply a specific treatment to dry and to freeze 
the microstructure (cryosublimation drying, solvent exchange, ...) in order to avoid the risk of further modifying the phase assemblage. However, the rehydration process is therefore not stopped during the storage, which may explain why some phases such as AFt phase (ettringite) appears more strongly in ${ }^{27} \mathrm{Al}$ NMR than in XRD, due to the lag of few days between these two characterizations.
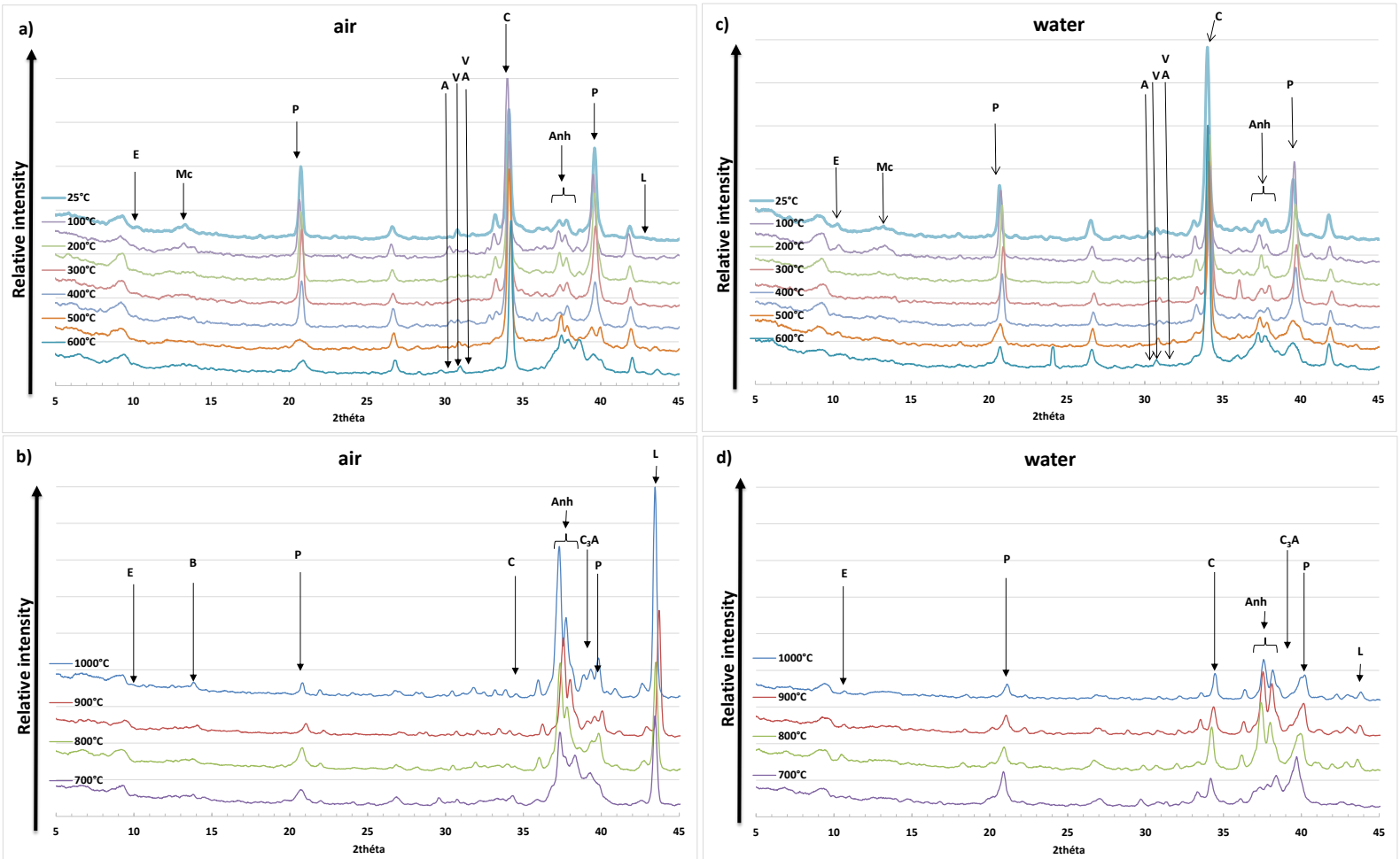

Figure 2: Partial XRD patterns of cement paste exposed at various temperatures and the same air or water cooling regime. Ettringite $(\mathrm{E})$, Portlandite $(\mathrm{P})$, calcite $(\mathrm{C})$, vaterite $(\mathrm{V})$, aragonite $(\mathrm{A})$, monocarboaluminate $(\mathrm{Mc})$, lime (L), Brownmillerite (B) and anhydrous phases $\mathrm{C}_{2} \mathrm{~S}$ and $\mathrm{C}_{3} \mathrm{~S}$ (Anh). 

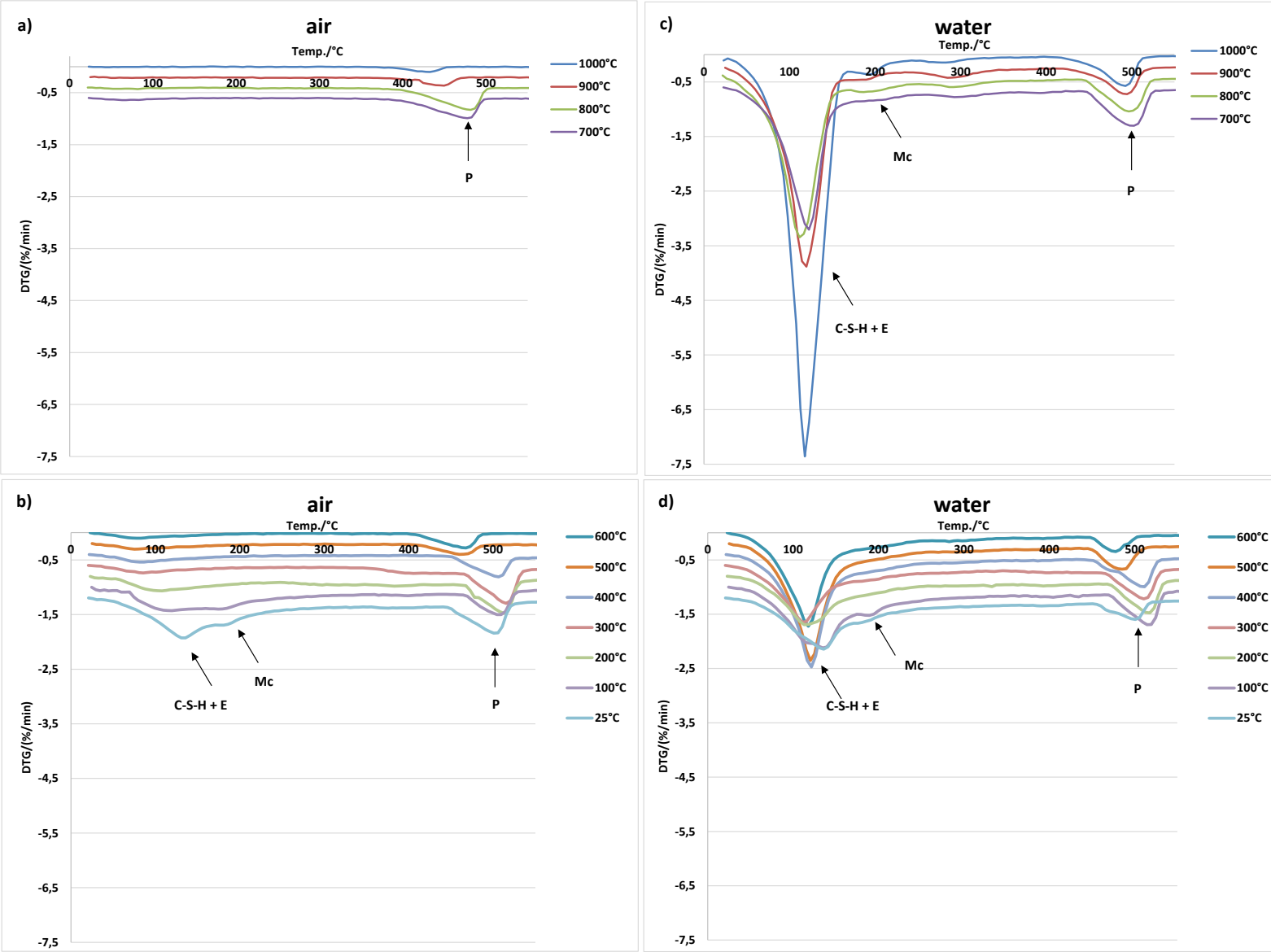

Figure 3: Partial DTG patterns of cement paste exposed at various temperatures and the same air or water cooling regime. Ettringite (E), Portlandite $(\mathrm{P})$, monocarboaluminate $(\mathrm{Mc})$.

The changes in the phase assemblage, shown in figure $1 \mathrm{a}$, refer to $100 \mathrm{~g}$ of material observed after heat treatment and cooling. However, with HT, there are significant weight losses (see figure 4, blue line ) and therefore, it is also necessary to report each hydrated phases to a fixed reference amount. In general, this last is the initial amount of clinker which can be obtained at $1000^{\circ} \mathrm{C}$ after $\mathrm{CO}_{2}$ loss by TGA. The results are presented in figures $5 \mathrm{a}$ and 6 . Indeed, the amount of some phases could increase due to the concentration of matter caused by weight losses of the other phases. In fact, weight losses observed (obtained after $\mathrm{HT}+\mathrm{AC}$ ) are attributed to the departure of the water up to $550^{\circ} \mathrm{C}-600^{\circ} \mathrm{C}$ $[1,3,15]$ and a weight loss of $\mathrm{CO}_{2}$ from $550^{\circ} \mathrm{C}$ which were verified here by TGA coupled mass spectroscopy. It was noticed that the sample after $25^{\circ} \mathrm{C}$, gains mass which is probably due to a slight carbonation and/or a humidification process from water of the air. The mass loss curve observed in figure 4 (blue line) is clearly not linear. In first approach, it seems to be characterized by three zones with various curve slopes. A first zone, between $25-300^{\circ} \mathrm{C}$, corresponds to the water losses of C-S-H, ettringite and AFm phases according to Refs $[1,3,15]$. A second zone, between $400-600^{\circ} \mathrm{C}$ corresponds mainly to the dehydroxylation of the portlandite with minor water losses from the other hydrated phases (in particular C-S-H) and also a small part of $\mathrm{CO}_{2}[1,3,15]$. Finally, a third zone, between 600$900^{\circ} \mathrm{C}$ corresponds to the decarbonation of calcium carbonates (mainly calcite according to XRD in figure $2 \mathrm{a}$ and $2 \mathrm{~b}$ ), as also observed by authors[1,3,15]. 


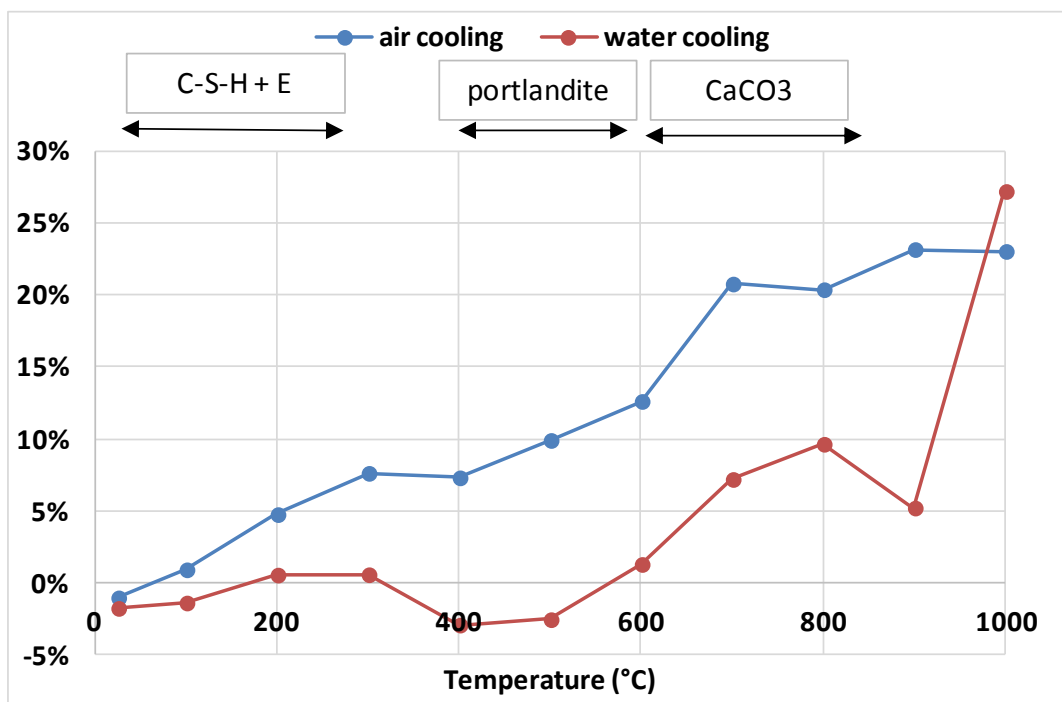

Figure 4: Weight loss of cement paste (in \%) obtained before and after exposition at various temperature and cooling (air cooling in blue line or water cooling in red line). The degradation of the main products responsible of the variation mass is indicated.
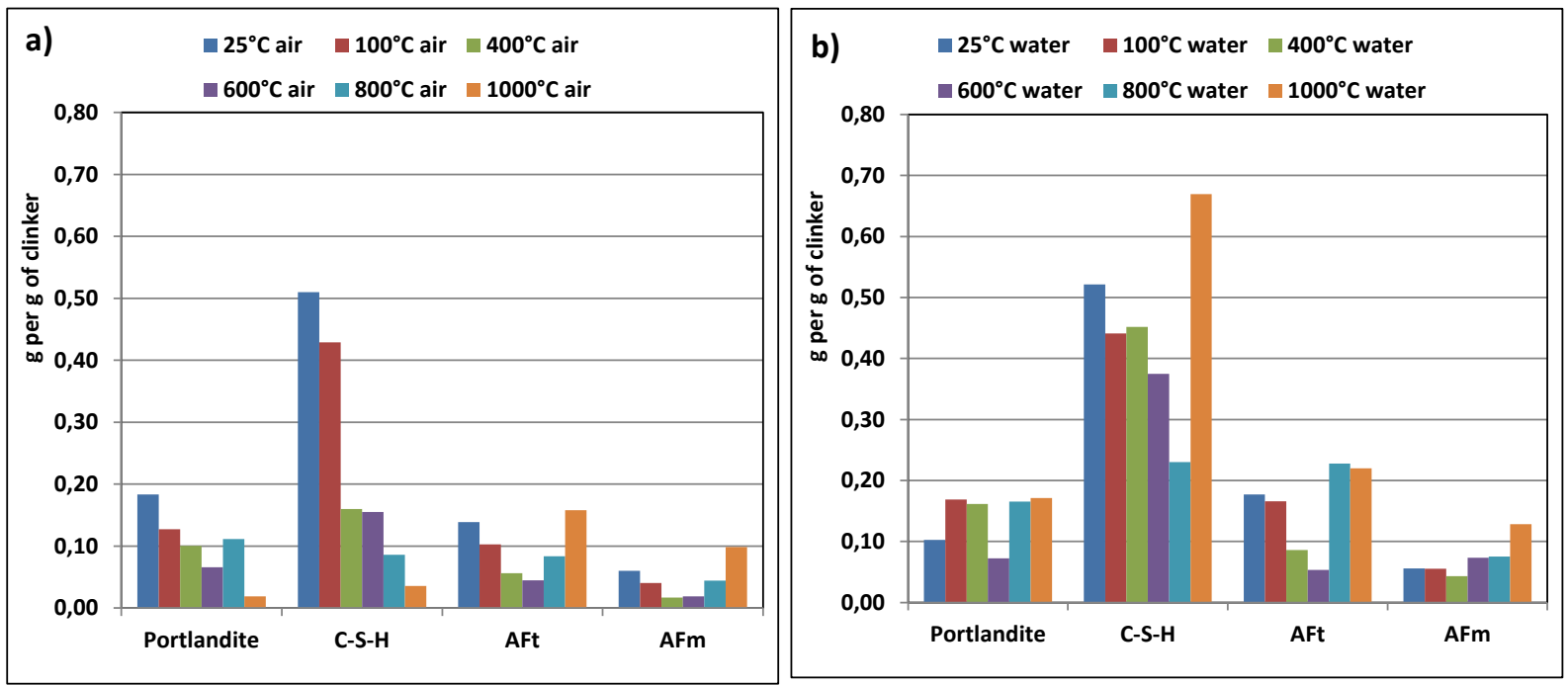

Figure 5: Mass proportion reported to clinker of the main hydrated phases, obtained by the combined technique [19]. The cement pastes are exposed at various temperature and air cooling (in left) or water cooling (in right). Here C-S-H= C-S-H+silica gel, AFt=Ettringite and AFm=Monocarboaluminate, Hemicarboaluminate and Monosulfoaluminate. 

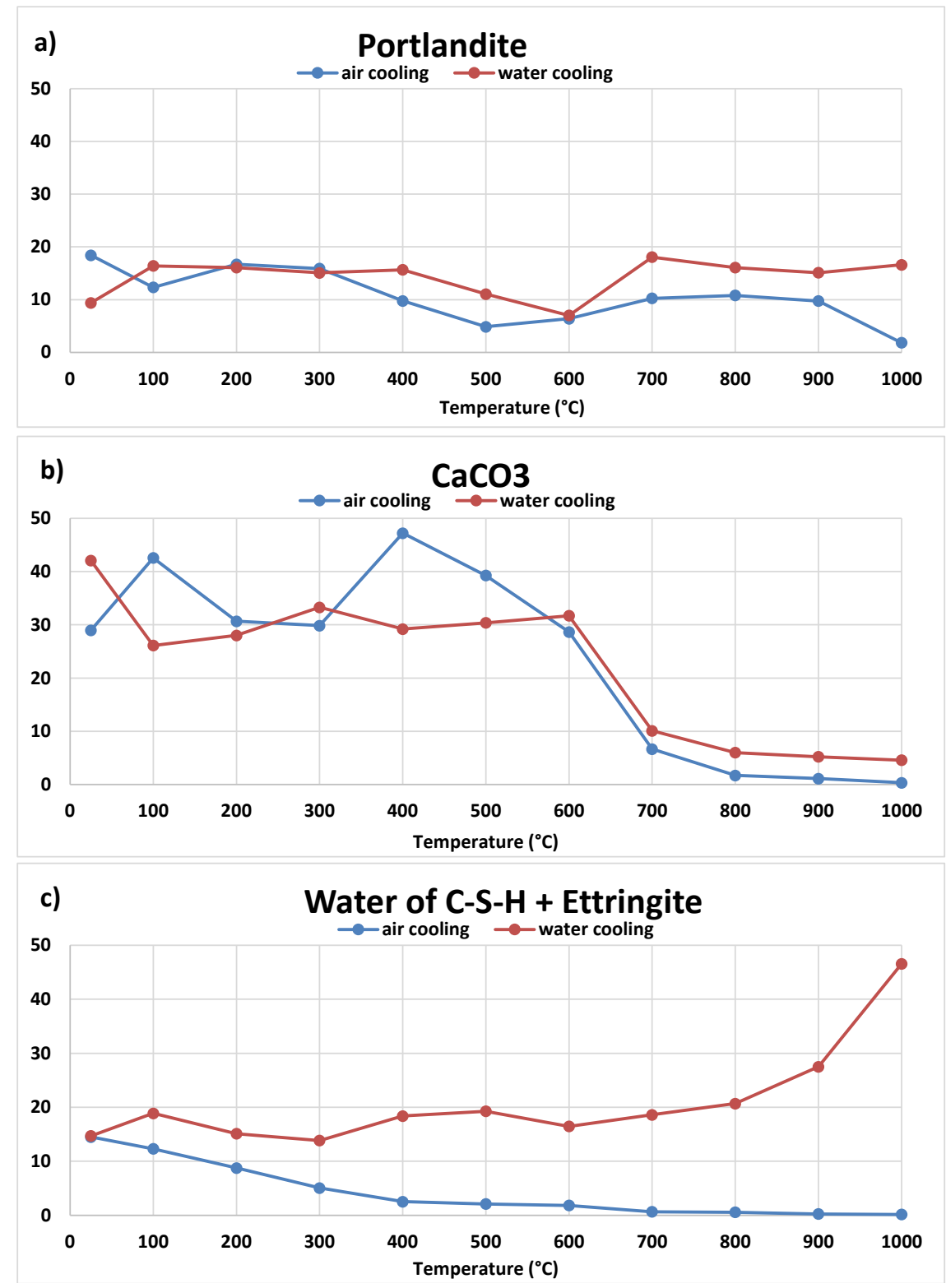

Figure 6: Mass proportion (\%) reported to clinker obtained by TGA. The cement pastes are exposed to various temperature and same cooling regime (air cooling in blue or water cooling in red).

3.1.2 Temperature effect with AC on equilibrium of portlandite $\left(\mathrm{Ca}(\mathrm{OH})_{2}\right)$, lime $(\mathrm{CaO})$ and calcium carbonates $\left(\mathrm{CaCO}_{3}\right)$

In detailed results, the portlandite amount (reported to the initial amount of clinker) slowly decreases from $25^{\circ} \mathrm{C}$ to $300^{\circ} \mathrm{C}$ (see figure $6 \mathrm{a}$ in blue line). For the sample at $100^{\circ} \mathrm{C}$, the decrease is significant, it can come from the carbonation of the sample which can be facilitated by the temperature according to [20]. In addition, since the sample is air cooled and it is small, it facilitates the interactions with air. For samples at $200^{\circ} \mathrm{C}$ and $300^{\circ} \mathrm{C}$, the drying is stronger and could prevent this carbonation process (carbonation process needs water).

From $300^{\circ} \mathrm{C}$ to $500^{\circ} \mathrm{C}$, the amount of portlandite decreases strongly (a decrease of $60 \%$ compared to the reference value of the sample at $25^{\circ} \mathrm{C}$ ), which was expected since this corresponds to its degradation temperature $\left(450^{\circ} \mathrm{C}\right)$ [3]. However, for $500^{\circ} \mathrm{C}$ sample, it is still present. This means that a part of the $\mathrm{CaO}$ (lime), formed after $\mathrm{HT}$ as see in figure $2 \mathrm{a}$, was able to reform a small part of portlandite with the relative humidity of the air, during AC.

From $500^{\circ} \mathrm{C}$ to $900^{\circ} \mathrm{C}$, the amount rises but not to the same level as the original quantity (a reduction of $50 \%$ compared to the reference value of sample at $25^{\circ} \mathrm{C}$ ). For $1000^{\circ} \mathrm{C}$, portlandite amount is 
reduced and has the lowest value. For this temperature, a microstructural modification may cause a decrease of $\mathrm{CaO}$ reactivity after HT. Consequently, less portlandite can be reformed after that. Changes in the position of the portlandite peak are observed on DTG curves (see figure $2 \mathrm{a}$ and $2 \mathrm{~b}$ and see also TDA peak in table 3 in appendix). The temperature peak increases from the sample at $25^{\circ} \mathrm{C}$ to one at $300^{\circ} \mathrm{C}$, then it decreases from the sample at $400^{\circ} \mathrm{C}$ to the one at $1000^{\circ} \mathrm{C}$. The portlandite peaks on diffractogramms are wider for samples from $500^{\circ} \mathrm{C}$ to $1000^{\circ} \mathrm{C}$. These results therefore show differences in the structure of the portlandite as a function of the temperature used during HT as also observed by XRD (see table 3). Consequently, the thermal history of a cementitious material can be followed with portlandite, as previously observed [1,21].

$\mathrm{CaCO}_{3}$ amount (see figure $6 \mathrm{~b}$ in blue line) varies depending on the samples from $25^{\circ} \mathrm{C}$ to $400^{\circ} \mathrm{C}$. According to [20], the temperature promotes carbonation process, especially since the sample is air cooled and is relatively small as said in previous paragraph.

After $400^{\circ} \mathrm{C}$, the amount of $\mathrm{CaCO}_{3}$ decreases constantly in the samples. A stronger decrease is noted for the samples exposed between $600^{\circ} \mathrm{C}$ to $700^{\circ} \mathrm{C}$, which corresponds to the decarbonation temperatures of calcium carbonates $[1,3]$. After $700^{\circ} \mathrm{C}$, just a small part of $\mathrm{CaCO}_{3}$ can be reformed during cooling, unlike portlandite. This was quite expected since a relative humidifcation of the material is needed before the carbonation can begin. For samples exposed to temperatures after $700^{\circ} \mathrm{C}$, the $\mathrm{CaO}$ (lime) produced has a better tendency to form portlandite than to reform $\mathrm{CaCO}_{3}$. From XRD results (see figure $2 \mathrm{a}$ and $2 \mathrm{~b}$ ), $\mathrm{CaCO}_{3}$ is mainly calcite but other phases are also present such as vaterite and aragonite. In addition, thermal analyses show the presence of amorphous calcium carbonate. The distribution between the different phases of $\mathrm{CaCO}_{3}$ depends on a very large number of factors linked to carbonation, such as the level of $\mathrm{CO}_{2}$, relative humidity, temperature, the nature of the hydrated phases from it was formed [22].

In conclusion, with increasing temperature, both portlandite and calcium carbonates transform into $\mathrm{CaO}$ (lime according XRD) which gradually increases from $400^{\circ} \mathrm{C}$. However, $\mathrm{AC}$ can produce some calcium carbonates and some hydrated phases with the humidity of the air, depending on the reactivity of the phases obtained after each HT.

\subsubsection{Temperature effect with AC on equilibrium of $C$-S- $H$ and anhydrous phases $\left(C_{2} S\right.$ and $\left.C_{3} S\right)$}

C-S-H amount decreases with the rise of temperature (see figure 1a and 5a). For samples up to the temperature of $400-600^{\circ} \mathrm{C}$, there are mainly quantities of water that leave (see figure $6 \mathrm{c}$ ). The $\mathrm{C}-\mathrm{S}-\mathrm{H}$ chains condense to form silica gel since an increase of $\mathrm{Q}^{3}$ and $\mathrm{Q}^{4}$ species and also an increase in average chain lengths (MCL) are observed (see figure $7 \mathrm{~b}$ ) and also an increase of $\mathrm{Q}^{1}$ and $\mathrm{Q}^{2}$ width in Table 5. All these results mean that C-S-H becomes a more disordered phase. This condensation process releases structural water which is evaporated during HT.

For samples exposed from $400^{\circ} \mathrm{C}$ to $1000^{\circ} \mathrm{C}$, there is a decrease of $\mathrm{Q}^{1}$ and $\mathrm{Q}^{2}$ species but also a decrease of $\mathrm{Q}^{3}$ and $\mathrm{Q}^{4}$ species in favor of $\mathrm{Q}^{\circ}$ species (see figure 7a). Consequently, there is a reformation of anhydrous phases such as lime but also such as $\mathrm{C}_{2} \mathrm{~S}$ and $\mathrm{C}_{3} \mathrm{~S}$ as shown by NMR and XRD. It can be noticed no significant change in the position of the peaks for the $C_{2} S$ (except width). However, other authors presented a shift of the $\mathrm{C}_{2} \mathrm{~S}$ peak [3]. It is possible, since the NMR tests here are performed after few days, that $\mathrm{C}_{2} \mathrm{~S}$ structure can evolve with time. For samples exposed to temperatures superior or equal to $600^{\circ} \mathrm{C}$, the $\mathrm{MCL}$ varies strongly but, in MCL calculation formula, the quantities of $\mathrm{Q}^{1}$ and $\mathrm{Q}^{2}$ become very low $(<10 \%)$ causing high variations of calculation. Consequently, the uncertainties become wider. 


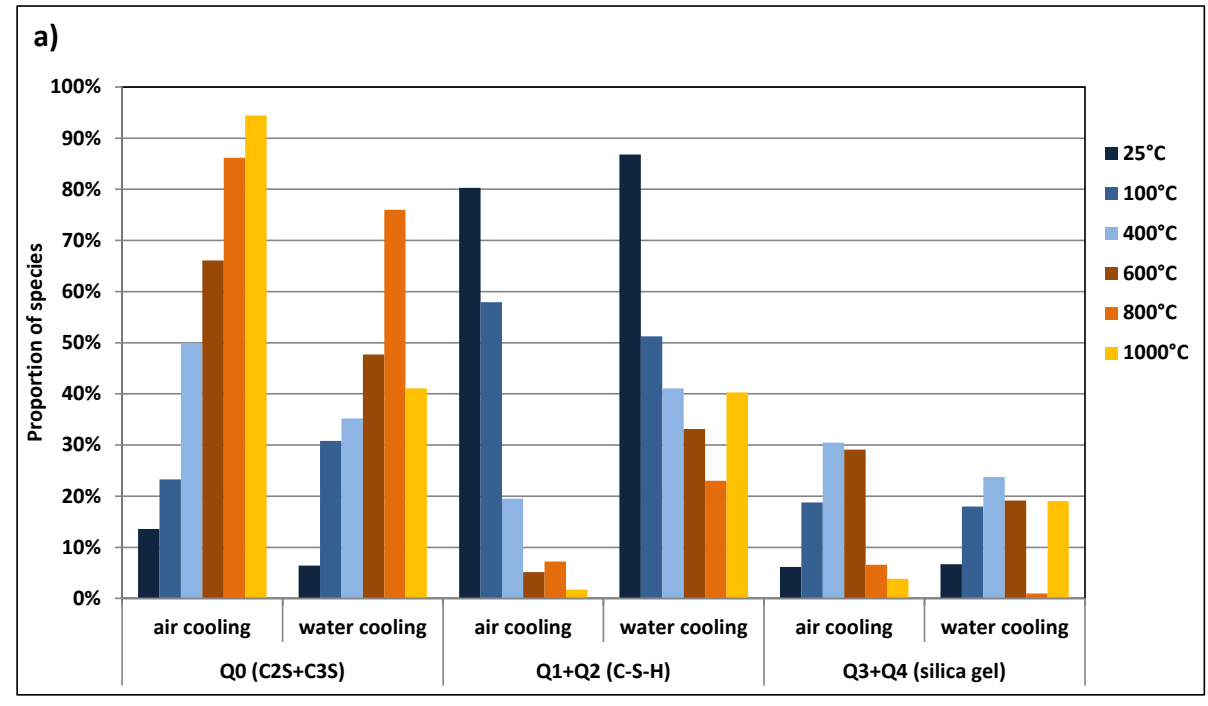

b)

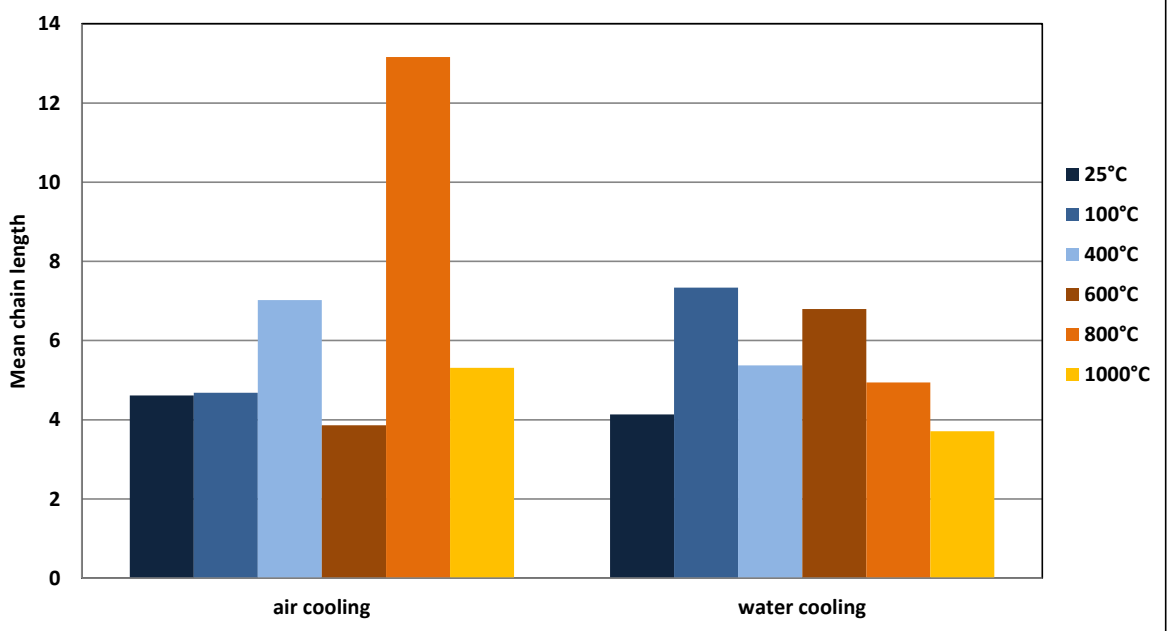

Figure 7: Molar proportion of species and mean chain length (MCL) of C-S-H obtained by ${ }^{29} \mathrm{Si}$ NMR. The cement pastes are exposed to various temperature, and air cooling or water cooling.

\subsubsection{Temperature effect with AC on equilibrium of aluminate phases and general thermodynamic diagrams}

The amount of ettringite (AFt phase) decreases until reaching $500^{\circ} \mathrm{C}$ (see figure 8a). This mainly concerns the water contained in the ettringite for the sample at $100^{\circ} \mathrm{C}$ (see figure $3 \mathrm{a}$ and $3 \mathrm{~b}$ and see also C-S-H+Ettringite blue curve in figure $6 \mathrm{c}$ ). In addition, the ${ }^{27} \mathrm{Al}$ NMR shows a reduction of $\mathrm{AFt}$ amount, which means that ettringite is partially degraded as seen before [23-25]. However, there is still ettringite in all samples and the quantities of ettringite increase for samples exposed from $600^{\circ} \mathrm{C}$ to $1000^{\circ} \mathrm{C}$. Consequently, the samples during $\mathrm{AC}$ were able to reform these hydrated phases from the relative humidity of the air, as already observed $[3,7,8]$. In addition, for samples exposed from $600^{\circ} \mathrm{C}$, there may be an increase in reactivity to form these hydrated phases since their quantity increases. On the other hand, the diffractogramms no longer show ettringite in crystalline form, whatever the HT (except the reference sample at $25^{\circ} \mathrm{C}$ ). Ettringite may lose its crystallinity during $\mathrm{HT}$ and therefore it does not appear in XRD [24]. In addition, deconvolution of ${ }^{27} \mathrm{Al}$ NMR spectra (see table 3 ) shows that FWHH of AFt phase (ettringite) increases in the range of $100-600^{\circ} \mathrm{C}$ which means a modification of the structure. Ettringite becomes a more disordered phase. Additional XRDs (not figured here) were made on the samples after the NMR characterizations, as a result, they show a small peak for ettringite for higher temperature $\left(>800^{\circ} \mathrm{C}\right)$ unlike those which were performed a few hours after AC. More time seems to be needed to reform and to crystallize ettringite. 
The amount of AFm phase evolves in a similar manner as those of AFt phases. The peak shape and its position are modified according to the temperature which means modifications of the structure and, possibly, of AFm type. However, as for Ettringite, there is no cristallised peak for AFm in diffractogramm except to monocarboaluminates for samples at $25^{\circ} \mathrm{C}$ and $100^{\circ} \mathrm{C}$, confirmed by DTG (see figure $3 \mathrm{a}$ and $3 \mathrm{~b}$ ). In addition, when AFt phases are degraded, sulphate is freed but there is no trace of a phase formation with this element (e.g. $\mathrm{CaSO}_{4}$ anhydrite or gyspsum).

Moreover, for lower temperature exposure, the amount of TAH remains constant and then it decreases from $300^{\circ} \mathrm{C}$ to $600^{\circ} \mathrm{C}$ and then stays low with small variations. This phase probably loses its water during HT. A small part can be reform during AC.

The amounts of $\mathrm{Al}\left(\mathrm{IV}\right.$ ) (assigned to $\mathrm{Al}$ substituted to $\mathrm{Si}$ or $\mathrm{Ca}$ in $\mathrm{C}-\mathrm{S}-\mathrm{H}$ ) increase to $500^{\circ} \mathrm{C}$. This could be explained by the fact that both AFm and AFt phases degrade and therefore that the $\mathrm{Al}(\mathrm{VI})$ becomes $\mathrm{Al}(\mathrm{IV})$, more in the form of an alumina gel precipitating at the surface of $\mathrm{C}-\mathrm{S}-\mathrm{H}$ than $\mathrm{Al}$ actually incorporated in $\mathrm{C}-\mathrm{S}-\mathrm{H}$.

From $500^{\circ} \mathrm{C}$ to $1000^{\circ} \mathrm{C}$, these amounts of $\mathrm{Al}(\mathrm{IV}$ ) (two peaks grouped in one contribution on figure 8a) decrease strongly in favor of $\mathrm{Al}(\mathrm{IV})$ of another third species (the 3 peaks are well distinghished, see appendix), which is assumed to be $\mathrm{C}_{3} \mathrm{~A}$ or an equivalent anhydrous compound. This quantity increases to $700^{\circ} \mathrm{C}$, then it decreases in favor of the hydrated aluminate phases which are probably produced during AC. This means that the $\mathrm{C}_{3} \mathrm{~A}$ produced during $\mathrm{HT}$, would be more reactive from $700^{\circ} \mathrm{C}$.

However, there is no modification of the peak (position or width) in ${ }^{27} \mathrm{Al}$ NMR between the samples exposed to different temperatures (see table 4). Consequently, its structure seems not to be modified by temperature.

In the present discussion, the $\mathrm{C}_{4} \mathrm{AF}$ is assumed to be negligible because it could not be isolated and quantified with any techniques used here. However, the presence of a little brownmillerite amount (a form of $\mathrm{C}_{4} \mathrm{AF}$ ) is observed by $\mathrm{XRD}$ for the samples at $900^{\circ} \mathrm{C}$ and $1000^{\circ} \mathrm{C}$.

Finally, all these characterizations make it possible to create thermodynamic diagrams of species as a function of the temperature, for $\mathrm{AC}$ and by considering the chemistry of each of the main elements $\mathrm{Ca}$, $\mathrm{Si}$ and $\mathrm{Al}$ (see figure $9 \mathrm{a}, 9 \mathrm{~b}$ and $9 \mathrm{c}$ ). These diagrams can improve the already existing numerical simulations taking account the air cooling regime.
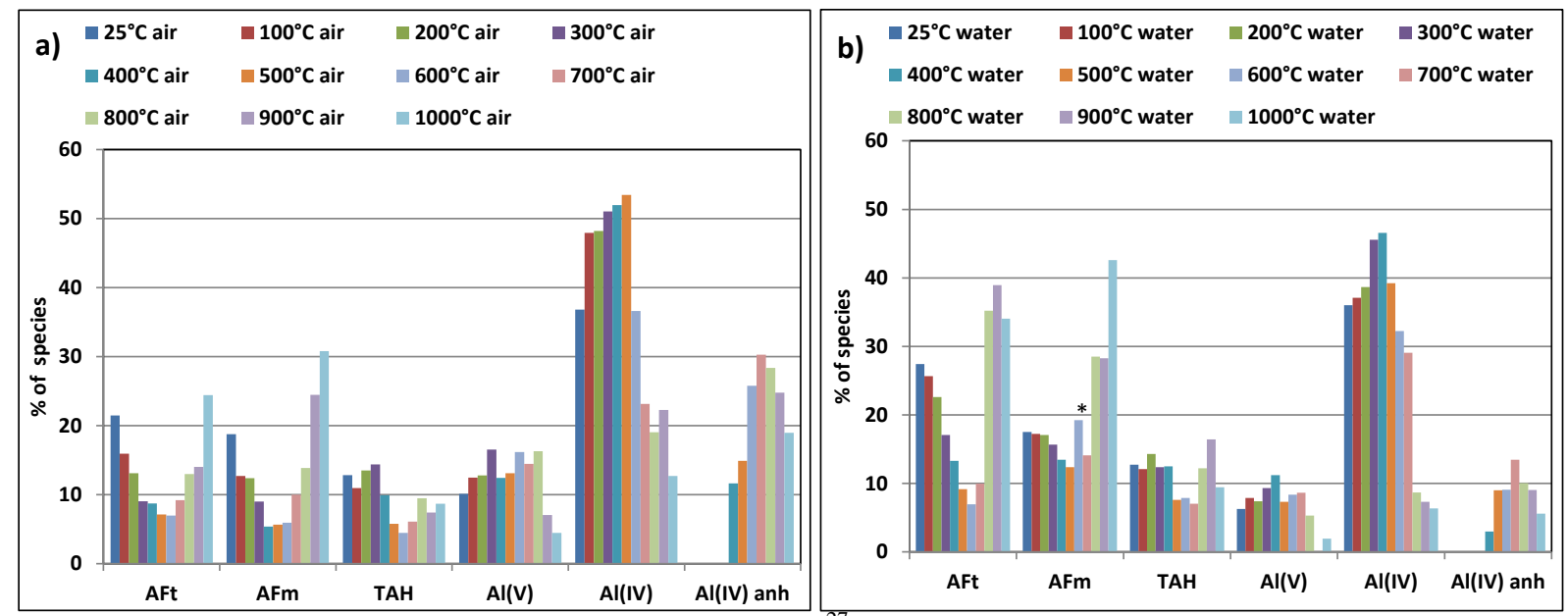

Figure 8: Molar proportion (\%) of Al species obtained by ${ }^{27} \mathrm{Al}$ NMR. The cement pastes are exposed at various temperature and the same air or water cooling regime. $\mathrm{Al}(\mathrm{V})$ and $\mathrm{Al}(\mathrm{IV})$ : $\mathrm{Al}$ substituted to $\mathrm{Si}$ in $\mathrm{C}-\mathrm{S}-\mathrm{H}$ or alumina gel. $\mathrm{Al}(\mathrm{IV})$ anh: $\mathrm{Al}$ supposed to be in $\mathrm{C}_{3} \mathrm{~A}$. (*): aberrant values. 


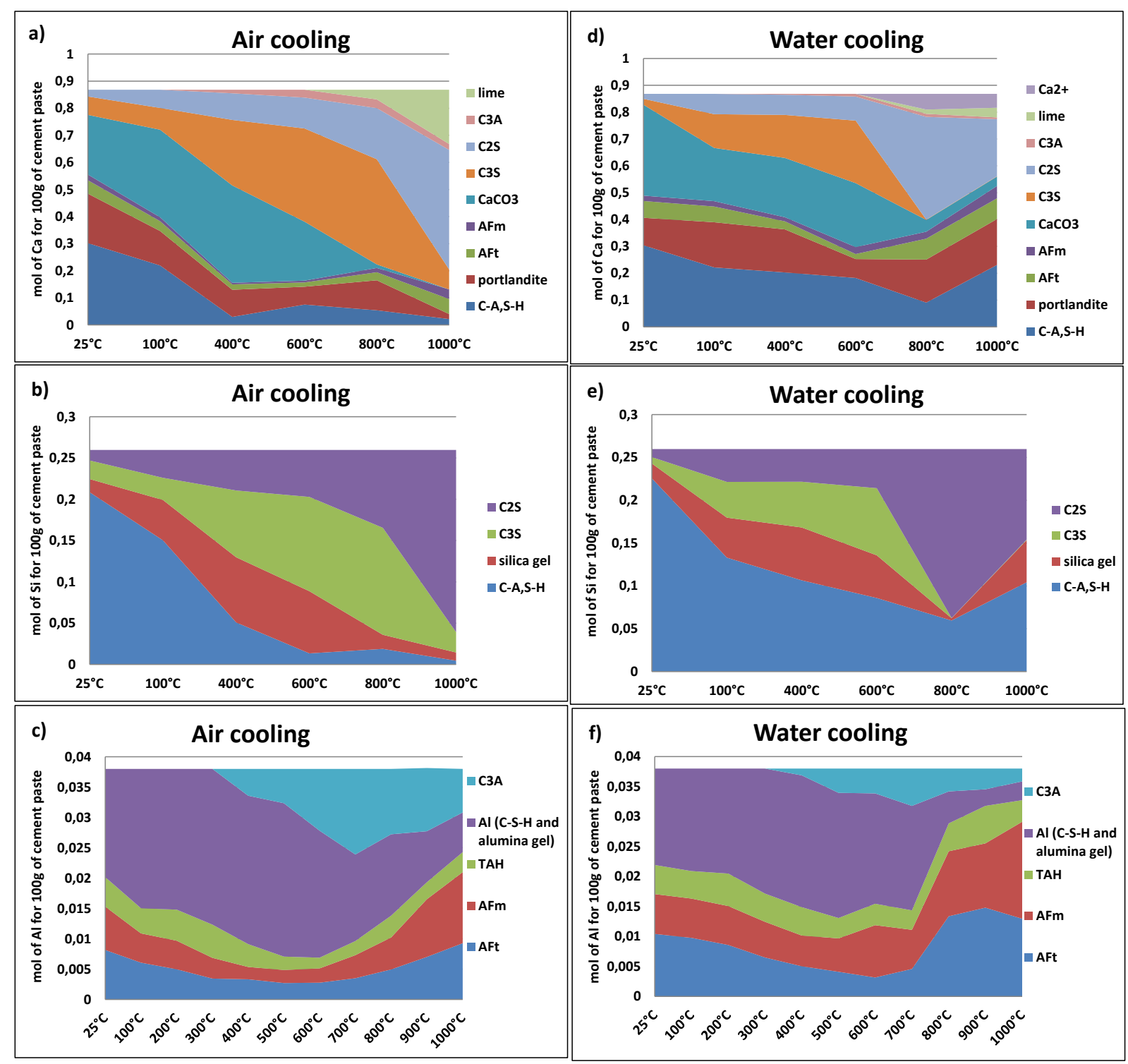

Figure 9: Evolution of the phase assemblage containing calcium, silicium and alumina as the function of the temperature and for the same cooling regime (Water or Air). Results are obtained by combined technique [19]. $25^{\circ} \mathrm{C}$ cement paste cooling at air served as reference. C-A,S-H is C-S-H with alumina substituted to Si or Ca. $\mathrm{Ca}^{2+}$ : calcium loss during contact of the materials and water.

\subsection{Comparison of water cooling regime (WC) with air cooling regime (AC)}

\subsubsection{General observations and leaching for WC}

First, after $\mathrm{HT}$ from $600^{\circ} \mathrm{C}$ to $1000^{\circ} \mathrm{C}$, the specimens, blow up at the contact with water during WC. A paper filter was used to collect debris. These debris were placed in the desiccator for 24 hours to dry. The explosion of these specimens is attributed to severe thermal gradients between the hot regions inside the specimen and the external surface submitted to the thermal shock induced by quenching in water. These thermal gradients induce high compressive stresses which causes the concrete specimens to blow up. In particular, for $1000^{\circ} \mathrm{C}$, it is possible that a part of materials was not totally recovered due to the smaller debris produced, explaining the high value of weight loss in figure 4 (red line).

Since the samples, exposed for all temperature with WC, were put in contact with water, it is interesting to see if ions have been able to go into solution. This was used in order to know the possible matter losses of the sample. In the same way as the leaching problems were observed on cementitious materials [26], three ions in particular are likely to go into solution: calcium, sodium and 
potassium. These ions were therefore quantified in contact solution by ICP-AES and the amounts found are reported to the initial quantity of cement paste (weight of the sample before HT). It allows them to be compared to the initial amounts of these ions in order to determine the proportion of leached ions.

The results are presented in figure 10. For calcium, the ion loss becomes significant (> 3\%) for sample exposed from $700^{\circ} \mathrm{C}$ and reaches almost $7 \%$ of the initial amount of calcium. For sodium and potassium, the losses are significant whatever the temperature, including that of reference. Reported to their initial amount, there are larger variations as the function of the temperature used. For these ions, the initial amounts were small $(<1 \%$, see Table 1$)$ than calcium one, the same for the both sodium and potassium amounts quantified by ICP-AES in the solutions used for WC. Consequently, the measurement uncertainties are particularly high for these two ions on the contrary of the calcium case.
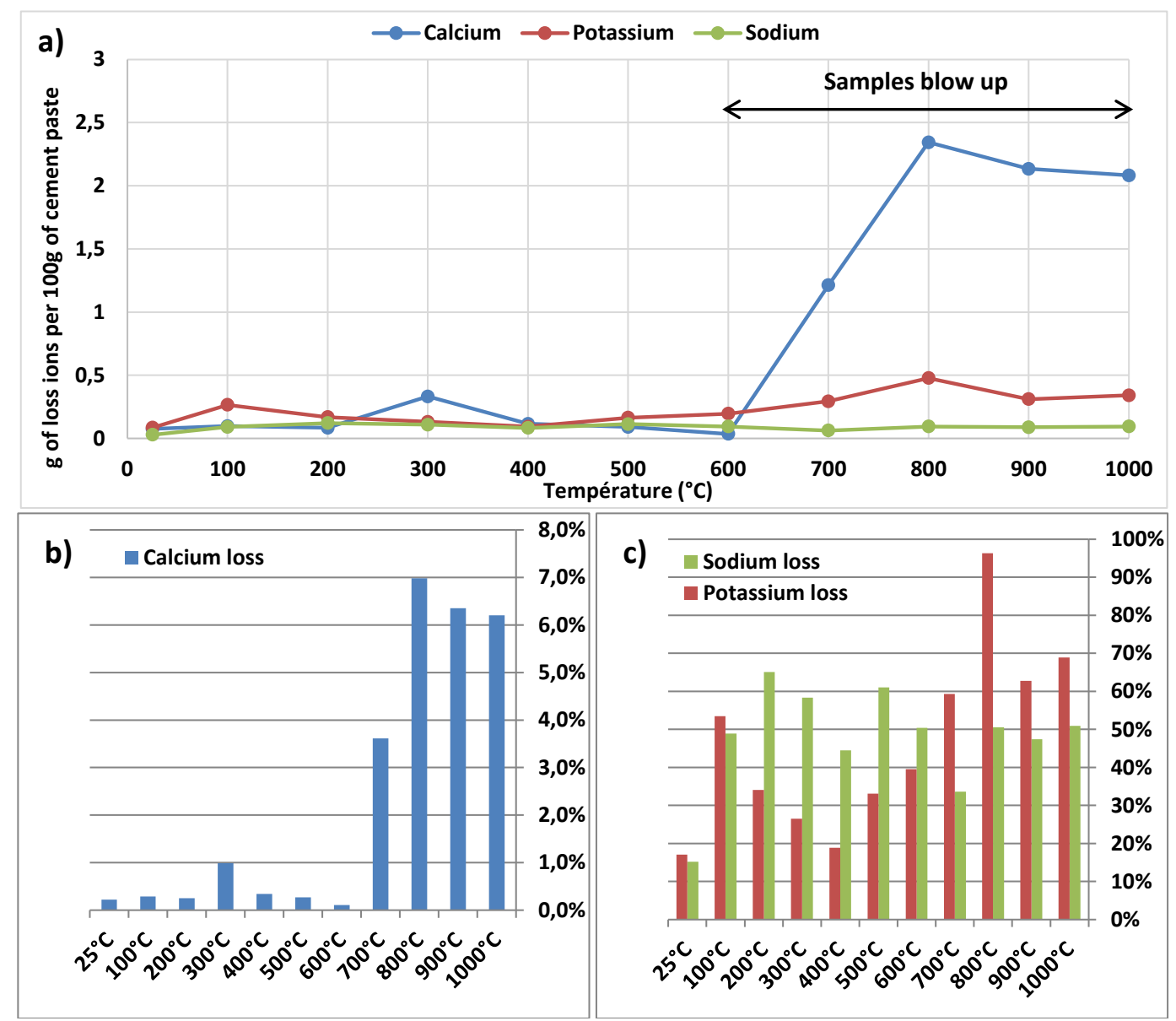

Figure 10: Matter loss (calcium, sodium and potassium) during water cooling obtained by ICP-AES. The cement pastes are exposed to various temperature and the same water cooling.

\subsubsection{Incorporation of water during WC and global comparison of phase assemblage with $A C$}

In figure 4, the mass losses are less important for WC than for $\mathrm{AC}$ as expected. In fact, several reasons explain these results. A part of the water is still incorporated into the porosity (despite the drying step in the desiccator after WC), in addition to the water incorporated during the formation of new hydrated products. In fact, drying after WC only lasted 24 hours. Obviously, it is insufficient to evaporate all the water contained in the pores.

Moreover, the separation of the water chemically contained in C-S-H from the one in the porosity is particularly difficult to obtain as the first temperatures of C-S-H drying is inferior to $100^{\circ} \mathrm{C}[19,27,28]$. The determination of water in C-S-H has been the subject of numerous studies such as that by sorption isotherms [29]. It depends on the nature of the C-S-H (C/S, incorporation of $\mathrm{Al}$, mean chain length, surface...) which, in the present case, is modified by the temperature, as seen in section 3.1. 
In addition, after the highest temperatures, the anhydrous phases $\left(\mathrm{C}_{2} \mathrm{~S}\right.$ and $\left.\mathrm{C}_{3} \mathrm{~S}\right)$ are present in high quantities (see figure 1) and they are probably available (no hydrated phases on their surface).

Consequently, they can bind a part of the water on their surface during $\mathrm{WC}$, which is a prelude to their hydration [30]. It is therefore difficult to say about the TGA results of our samples, whether it is chemically bound water of C-S-H or free water in the pores. Within the calculations of our study, the water of C-S-H includes also there contained in the pores. This inevitably leads to an overestimation of the C-S-H amount, in particular for WC samples (see figure 1b). The $\mathrm{H} / \mathrm{S}$ ratios are given in Table 3. It is particularly noticed, that the $\mathrm{H} / \mathrm{S}$ ratios for $\mathrm{HT}$ at $800^{\circ} \mathrm{C}$ and $1000^{\circ} \mathrm{C}$ and $\mathrm{WC}$ are much higher than 4 , the usual values of C-S-H are generally between 1 and 4 . The quantities of water in the C-S-H for these samples are therefore probably overvalued for these samples.

In the same way as seen in section 3.1, the phase assemblage could be determined after WC (see figures $1 \mathrm{~b}$ and $5 \mathrm{~b}$ ). These results confirm those in Figure $2 \mathrm{c}$ and $2 \mathrm{~d}$. New hydrated products are formed after WC as already observed $[3,7,8]$ and their quantities are obviously overall higher than those obtained after AC. Moreover, the hydration rates obtained by ${ }^{29} \mathrm{Si}$ NMR (see figure 11) are higher for WC than the ones for $\mathrm{AC}$ (except temperature of $100^{\circ} \mathrm{C}$ ). For the reasons mentioned above concerning the water in the pores of the WC samples, it was not chosen to calculate this rate by the TGA technique [27], because the rates would be very overestimated. In general, figure $1 \mathrm{~b}$ shows variations for all phases depending on HT followed by WC. The detailed effect of cooling regime on each phase (comparison between AC and WC) will be presented in the following sections.

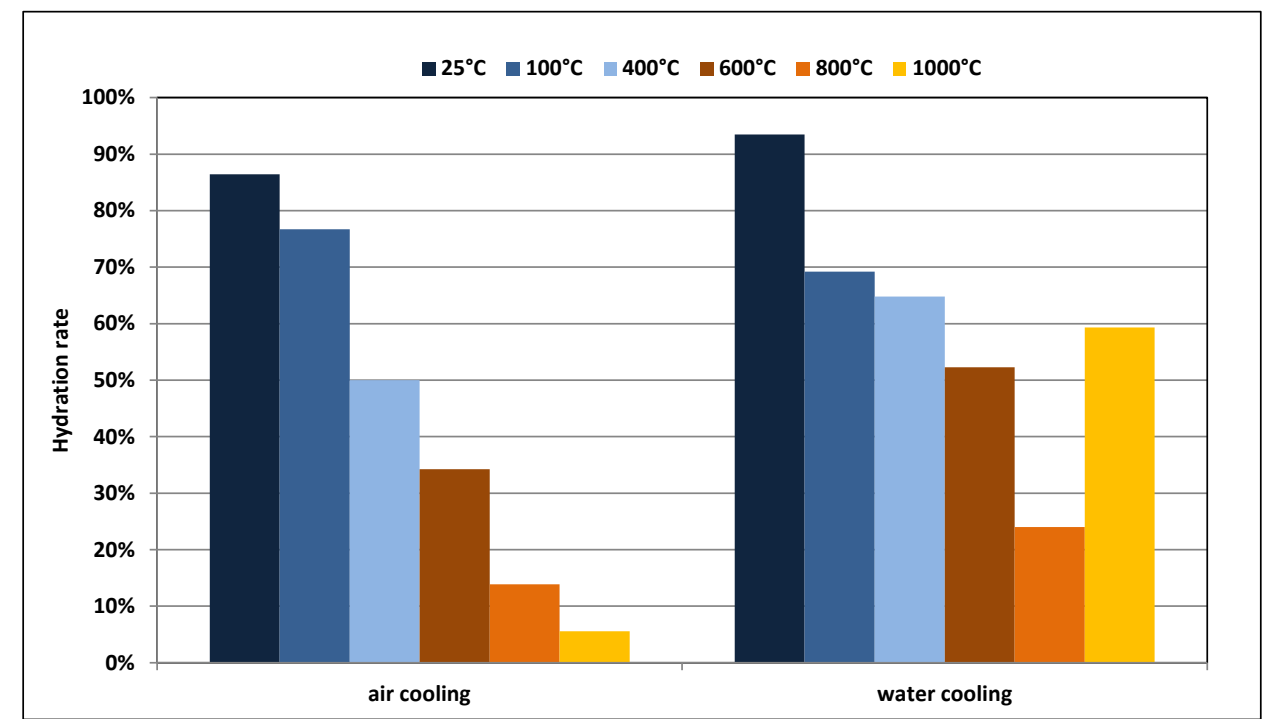

Figure 11: Hydration rate obtained by ${ }^{29} \mathrm{Si}$ NMR.

\subsubsection{Effect of the cooling regime on portlandite, lime and $\mathrm{CaCO}_{3}$}

In the sample at $25^{\circ} \mathrm{C}$, portlandite amount is higher for $\mathrm{WC}$ sample than for the $\mathrm{AC}$ one (see figure 6a). The difference is very high. This is due to the initial carbonation state of the sample. In fact, the quantity of $\mathrm{CaCO}_{3}$ is higher in the $\mathrm{WC}$ sample than in $\mathrm{AC}$ one and a priori there is no reason why carbonation should be so quick when sample is dived and then dried just $24 \mathrm{H}$.

This portlandite amount is higher in the WC sample exposed to $100^{\circ} \mathrm{C}$ than for one at $25^{\circ} \mathrm{C}$ and this amount is stable up to $400^{\circ} \mathrm{C}$, although less than that of the $\mathrm{AC}$ reference sample at $25^{\circ} \mathrm{C}$. This means that, as with the $\mathrm{AC}$ sample exposed to same temperature, this decrease of portlandite amount is partial.

Figure 6a (red line) also shows the existence of a minima value for $\mathrm{WC}$ sample exposed at $600^{\circ} \mathrm{C}$. This value is offset in comparison with AC samples (blue line). It seems that up to $400-500^{\circ} \mathrm{C}$, portlandite can be reformed in the presence of water, at least partially. At $600^{\circ} \mathrm{C}$, there is no difference between $\mathrm{AC}$ and WC. This quantity of portlandite returns to its level at $700^{\circ} \mathrm{C}$ compared to the $\mathrm{AC}$ reference sample at $25^{\circ} \mathrm{C}$ (but much higher than the values obtained by $\mathrm{AC}$ for same temperatures). Beyond $700^{\circ} \mathrm{C}$, this amount slightly decreases. 
It is interesting, for $\mathrm{WC}$ regime, to see evolutions of both portlandite amount and $\mathrm{CaCO}_{3}$ one (see figure $6 \mathrm{a}$ and $6 \mathrm{~b}$, red line). The latter decreases very strongly from $600^{\circ} \mathrm{C}$ to $700^{\circ} \mathrm{C}$ due to decarbonation process, against from $400^{\circ} \mathrm{C}$ for $\mathrm{AC}$ (blue line). The product formed (lime, $\mathrm{CaO}$ ) seems very reactive with water to reform portlandite during WC. This result is also observed by XRD when comparing $\mathrm{WC}$ and $\mathrm{AC}$ samples for $700^{\circ} \mathrm{C}$ (no $\mathrm{CaO}$ in figure $2 \mathrm{~d}$ for WC sample unlike for AC sample in figure $2 \mathrm{~b})$ and the amounts of $\mathrm{CaO}$ are much lower for higher temperatures $\left(800^{\circ} \mathrm{C}, 900^{\circ} \mathrm{C}\right.$ and $\left.1000^{\circ} \mathrm{C}\right)$.

From $700^{\circ} \mathrm{C}$, other anhydrous phases (than $\mathrm{CaO}$ ) can be formed, such as $\mathrm{C}_{3} \mathrm{~S}$ and $\mathrm{C}_{2} \mathrm{~S}$. Therefore, their rehydration (during WC) partly forms portlandite but also C-S-H and hydrated aluminates phases (see the following sections). This could explain the slight decreases in the amounts of portlandite for the samples exposed to temperatures from $700^{\circ} \mathrm{C}$ to $1000^{\circ} \mathrm{C}$ because calcium is shared with the other new hydrated products (C-S-H and hydrated aluminate phases).

However, the situation is more complicated and other interpretations could explain this decrease. In the present case of WC, it is like a hydration process in the first days. In fact, results could be due to the kinetics of hydration and probably after few days, the quantities would be similar. In fact, portlandite amount increases with time [19]. However, the drying step after WC slow down the hydration process and probably, this last will not be fully completed. Finally, on the DTG curves (figure $3 \mathrm{c}$ and $3 \mathrm{~d}$ ) obtained for WC samples, the same peak shifts are observed for the portlandite as for the AC samples and also some structure modifications are observed by XRD (see peak shift and width changes in table 3 ).

\subsubsection{Effect of the cooling regime on $C$-S-H and on anhydrous phases $\left(C_{3} S\right.$ and $\left.C_{2} S\right)$}

C-S-H amount (see figure $1 \mathrm{~b}$ and figure $5 \mathrm{~b}$ ) decreases for WC samples exposed from $25^{\circ} \mathrm{C}$ to $800^{\circ} \mathrm{C}$ and then increases for $1000^{\circ} \mathrm{C}$. The amounts of WC samples are similar for temperatures of $25^{\circ} \mathrm{C}$ and $100^{\circ} \mathrm{C}$ and higher for other temperatures compared to those of AC samples. These differences are due to the chemically incorporated water (figure $6 \mathrm{c}$ and table 3 ) but also to the variable amount of silicium in C-S-H compared to that in the anhydrous phases (see figure 7a).

As in AC samples, a part of the C-S-H tends also to form silica gel up to $400-600^{\circ} \mathrm{C}$ but in less quantity for WC samples. An increase of $\mathrm{Q}^{1}$ and $\mathrm{Q}^{2}$ width is also observed (see table 5) meaning C-S$\mathrm{H}$ becomes a more disordered phase, as for $\mathrm{AC}$ samples.

The trends for MCL are not clear (see figure 7b). It seems that MCL increases for WC samples exposed to $100^{\circ} \mathrm{C}, 400^{\circ} \mathrm{C}$ and $600^{\circ} \mathrm{C}$ in comparison to the one exposed to $25^{\circ} \mathrm{C}$. This would correspond to a disorganization and a decrease in the chemically bound water by polymerization of the C-S-H chains as observed for AC samples.

Then, there is a MCL decrease for WC samples from $600^{\circ} \mathrm{C}$ to $1000^{\circ} \mathrm{C}$. For this cooling regime, the quantities of $\mathrm{Q}^{2}$ and $\mathrm{Q}^{1}$ species are more significant (>20\%). Since the C-S-H tend to become anhydrous phases after $\mathrm{HT}$ (for temperatures superior to $600^{\circ} \mathrm{C}$ ) and then the samples are in contact with water during $\mathrm{WC}$, anhydrous phases tend to form short C-S-H chains. In fact, it corresponds to the first days of a "classical" process of hydration. Consequently, the more anhydrous phases produced during HT, the more short chains of C-S-H are produced during WC. In the following days or months (during hydration), these MCL values will also increase as shown [19,31].

\subsubsection{Effect of the cooling regime on aluminate phases and on general thermodynamic diagrams}

Concerning the aluminate phases, the same general changes for WC samples are observed as for AC samples (comparing figure 8a with figure 8b). There are minima values, towards temperatures of 500$600^{\circ} \mathrm{C}$ for the hydrated phases, in particular AFt (ettringite) and AFm. For this temperature interval, during cooling ( $\mathrm{AC}$ or $\mathrm{WC}$ ), the ettringite therefore has difficulty in reforming, even in the presence of water.

On the contrary, from $800^{\circ} \mathrm{C}$, the quantities of $\mathrm{AFm}$ and $\mathrm{AFt}$ phases increase and exceed the quantities observed at $25^{\circ} \mathrm{C}$. This is confirmed by XRD where the peaks reappear from the temperature of $800^{\circ} \mathrm{C}$ to $1000^{\circ} \mathrm{C}$ (see also figure 2). 
In addition, the quantities of anhydrous $\mathrm{Al}(\mathrm{IV})$ are much lower for WC samples than for AC samples, therefore these $\mathrm{Al}(\mathrm{IV})$ phases participate in the formation of hydrated aluminate phases. As for $\mathrm{AFt}$ phase, AFm phases also increase for higher temperatures, but diffractogramm does not show any particular phase (see figure 2b). However, DTG curve shows a small peak which can be monocarboaluminate (or maybe hemicarboaluminate) for the temperature at $1000^{\circ} \mathrm{C}$. In addition, there are modifications of the AFm and AFt peaks (see table 4) but the tendencies are less clear than in the AC samples. The $\mathrm{Al}(\mathrm{IV})$ anh peak is also modified (position and width) according the temperature. The equilibrium of the hydrated phases and in particular the $\mathrm{AFm} / \mathrm{AFt}$ ratio is presented in figure 12 . The latter ratio is lower for $\mathrm{WC}$ samples than for $\mathrm{AC}$ samples from $25^{\circ} \mathrm{C}$ to $300^{\circ} \mathrm{C}$ and from $800^{\circ} \mathrm{C}$ to $1000^{\circ} \mathrm{C}$ as expected. In fact, the contact of cementitious materials with water is known to contribute to the formation of ettringite $[20,32,33]$. On the contrary, this seems to be reversed for the intermediate temperatures of $400-700^{\circ} \mathrm{C}$. It is quite difficult to determine why. At these temperatures, $\mathrm{SO}_{3}$ may be form a less reactive phase due to $\mathrm{WC}$ and then less dissolved $\mathrm{SO}_{3}$ would cause less ettringite formation. As part of our study, no techniques were used to directly probe this element. Consequently, it is not possible to confirm where $\mathrm{SO}_{3}$ is and, most importantly, in what phase.

In the same way as for AC samples, thermodynamic diagrams of species could be obtained for WC samples (see figure 9d, 9e and 9f) and will help to improve modelizations according the cooling regime. In addition, they quantitatively show the differences between the two cooling regime and they synthesize the results obtained in this study.

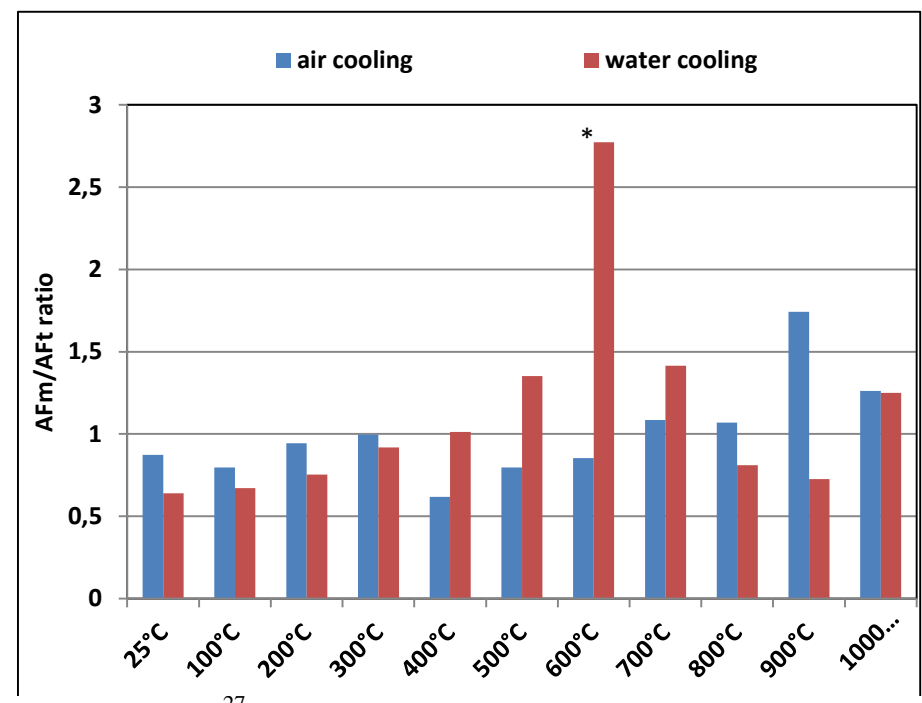

Figure 12: AFm/AFt ratio obtained by ${ }^{27} \mathrm{Al} \mathrm{NMR}$. The cement pastes are exposed to various temperature and the same water cooling. $\mathrm{Al}(\mathrm{V})$ and $\mathrm{Al}(\mathrm{IV})$ : $\mathrm{Al}$ substituted to $\mathrm{Si}$ in $\mathrm{C}-\mathrm{S}-\mathrm{H}$ or alumina gel. $\mathrm{Al}(\mathrm{IV})$ anh: $\mathrm{Al}$ supposed to be in $\mathrm{C}_{3} \mathrm{~A}$.

\section{Conclusion}

This paper deals with air cooling regime compared to water cooling regime in the thermal stability and microstructural changes of cement paste. For this purpose, blocks of unprotected five year-old cement paste, were heated up to various temperatures, up to $1000^{\circ} \mathrm{C}$, in steps of $100^{\circ} \mathrm{C}$. Materials are then characterized using DTA/TGA, XRD and NMR spectroscopy. Combination of these techniques allows creation of thermodynamics diagrams, which will be used to improve modeling in future studies.

This study confirms the presence of all hydrated phases even after their degradation temperature which means that, during cooling (air or water), a part of the materials can react with water (due to relative humidity in the air or directly if the materials is in contact with water) to form new hydrated phases. However, even if these new hydrated phases are present after cooling, there is a minima value of their amount for a specific temperature interval (portlandite, $\mathrm{AFm}$ and $\mathrm{AFt}$ ). In general, this interval corresponds to the degradation temperature of this phase such as portlandite $\left(500-600^{\circ} \mathrm{C}\right)$ but not for 
some other phases such as ettringite (minima value corresponding to $500-600^{\circ} \mathrm{C}$ ). Those results mean that reactivity of unhydrated/altered phases obtained after each heating treatment can vary. In addition, C-S-H degrades progressively with temperature increase (first, water loss, chains polymerization, transformation in gel silica structure and finally, formation of anhydrous phases such as $\mathrm{C}_{2} \mathrm{~S}$ and $\mathrm{C}_{3} \mathrm{~S}$ ).

Hydrated alumina phases tend to become an alumina gel or very disordered phases for exposition temperature inferior to $500^{\circ} \mathrm{C}$ and unhydrated phases for temperature superior to $600^{\circ} \mathrm{C}$.

Concerning the main differences between air cooling regime and water cooling regime, the thermal shock due to the water quenching has induced a blow up of the specimens heated above $500^{\circ} \mathrm{C}$. In real case of fire with water cooled regime, cracks happen in concrete leading to a decrease of mechanical and durability properties. Another consequence is leaching of elements (calcium, sodium and potassium). The sample can lose $8 \%$ of its calcium in solution after being heated treatment. This can participate to increase porosity and consequently to decrease durability properties of the materials exposed to fire then cooled with water.

Obviously, the amount of hydrated phases is greater in case of water cooling and therefore phase assemblage is also different. Even the equilibrium between hydrated phases is also quite different such as $\mathrm{AFm} / \mathrm{AFt}$ ratio between the two regimes. For both regime, sulphate released after heating has an uncertain future. A part can form hydrated aluminate phases such ettringite and especially in presence of water. It is possible, there is a risk of an internal sulphate attack after few year, for concrete exposed to fire.

After exposition to higher temperature and then water cooling, phase assemblage of the sample is not the same as before exposition. The hydration process can continue and it is not totally excluded that the sample will recover its initial phase assemblage without performing tests at a longer age. However, the process needs water. In fact, in the real case for concrete exposed to fire, the progressive drying after water cooling will limit hydration process and consequently both durability and mechanical properties will probably decrease.

\section{The authors declare that they have no conflict of interest.}

\section{Acknowledgements}

The authors are grateful to Jean-Baptiste d'Espinose de Lacaillerie (ESPCI-Paris) for NMR experiments.

\section{References}

[1] L. Alarcon-Ruiza, G. Platret, E. Massieu, A. Ehrlacher, The use of thermal analysis in assessing the effect of temperature on a cement paste, Cement and Concrete Research 35 (2005) 609-613. https://doi.org/10.1016/j.cemconres.2004.06.015.

[2] Z. Shui, D. Xuan, W. Chen, R. Yu, R. Zhang, Cementitious characteristics of hydrated cement paste subjected to various dehydration temperatures, Construction and Building Mateials 23(2009) 531-537. https://doi.org/10.1016/j.conbuildmat.2007.10.016.

[3] C. Alonso, L. Fernandez, Dehydration and rehydration processes of cement paste exposed to high temperature environments, J. Mater. Sci. 39 (2004) 3015-3024.

https://doi.org/10.1023/B:JMSC.0000025827.65956.18.

[4] M. Castellote, C. Alonso, C. Andrade, X. Turrillas, Campo J, Composition and microstructural changes of cement pastes upon heating, as studied by neutron diffraction, Cement and Concrete Research 34 (2004) 1633-1644. https://doi.org/10.1016/S0008-8846(03)00229-1.

[5] S.K. Handoo, S. Agarwal, S.K. Agarwal, Physicochemical, mineralogical, morphological characteristics of concrete exposed to elevated temperatures, Cement Concrete Research 32 (2002) 1009-1018. https://doi.org/10.1016/S0008-8846(01)00736-0.

[6] J. Piasta, Z. Sawicz, L. Rudzinski, Changes in the structure of hardened cement paste due to high temperature. Matériaux et constructions 17 (1984) 291-296. https://doi.org/10.1007/BF02479085. 
[7] G. Wang, C. Zhang, B. Zhang, Q. Li, Z. Shui, Study on the high-temperature behavior and rehydration characteristics of hardened cement paste, Fire and materials 39 (2015) 741-750. https://doi.org/10.1002/fam.2269.

[8] M. Vysvaril, P. Bayer, M Chroma, P. Rovnanikova, Physico-mechanical and microstructural properties of rehydrated blended cement pastes, Construction and Building Materials 54 (2014) 413 420. https://doi.org/10.1016/j.conbuildmat.2013.12.021.

[9] H. Sabeur, G. Platret, J. Vincent, The effect of ageing and heat treatment on microstructure evolution of a commercial cement paste, Heat and Mass Transfer 53 (2017) 2609-2626. https://doi.org/10.1007/s00231-017-2004-9.

[10] H. Sabeur, G. Platret, J. Vincent, Composition and microstructural changes of aged cement pastes upon two heating-cooling regimes, as studied by thermal analysis and X-ray diffraction, Journal of Thermal Analysis and Calorimetry 126 (2016) 1023-1043. https://doi.org/10.1007/s10973-016-5639$\underline{8}$.

[11] H. Sabeur, M. Saillio, J. Vincent, Thermal stability and microstructural changes in 5 years aged cement paste subjected to high temperature plateaus up to $1000^{\circ} \mathrm{C}$ as studied by thermal analysis and X-Ray Diffraction, Heat and Mass Transfer 55 (2019) 2483-2501. https://doi.org/10.1007/s00231-01902599-w.

[12] G. Peng, S. Bian, Z. Guo, J. Zhao, X. Peng, Y. Jiang, , Construction and Building Materials, 22 (2008) 948-955. https://doi.org/10.1016/j.conbuildmat.2006.12.002

[13] A.S.M Abdul Awal, I.A. Shehu, M. Ismail, Effect of cooling regime on the residual performance of high-volume palm oil fuel ash concrete exposed to high temperatures, Construction and Building Materials 98 (2015) 875-883. https://doi.org/10.1016/j.conbuildmat.2015.09.001

[14] L. Li, P. Jia, J. Dong, L. Shi, G. Zhang, Q. Wang, Effects of cement dosage and cooling regimes on the compressive strength of concrete after post-fire-curing from $800^{\circ} \mathrm{C}$, Construction and Building Materials 142 (2017) 208-220. https://doi.org/10.1016/j.conbuildmat.2017.03.053.

[15] K. Scrivener, R. Snellings, B. Lothenbach, A Practical Guide to Microstructural Analysis of Cementitious Materials, CRC press, Boca Raton, 2016. https://doi.org/10.1201/b19074.

[16] G. Engelhardt, D. Michel, High resolution 29Si NMR of silicates and Zeolites, Wiley, New York, 1987.

[17] J. Skibsted, E. Henderson, H.J. Jakobsen, Characterization of calcium aluminate phases in cements by 27Al MAS NMR spectroscopy, Inorganic Chemistry 32 (1993) 1013-1027.

https://doi.org/10.1021/ic00058a043.

[18] D. Massiot, F. Fayon, M. Capron, I. King, S. Le Calvé, B. Alonso, J.O. Durand, B. Bujoli, Z.

Gan, G. Hoatson, Modelling one and two-dimensional solid-state NMR spectra, Magnetic Resonance in Chemistry 40 (2002) 70-76. https://doi.org/10.1002/mrc.984.

[19] M. Saillio, V. Baroghel-Bouny, M. Bertin, S. Pradelle, J. Vincent, Phase assemblage of cement pastes with SCM at different ages, Construction and Building Materials 224 (2019) 144-157.

https://doi.org/10.1016/j.conbuildmat.2019.07.059.

[20] E. Drouet, S Poyet, P. Le Bescop, J.M. Torrenti, X. Bourbon, Carbonation of hardened cement pastes: Influence of temperature, Cement and Concrete Research 115 (2019) 445-459.

https://doi.org/10.1016/j.cemconres.2018.09.019.

[21] E. Annerel, L. Taerwe, Revealing the temperature history in concrete after fire exposure by microscopic analysis, Cement and Concrete Research 39 (2009) 1239-1249.

https://doi.org/10.1016/j.cemconres.2009.08.017.

[22] C Andrade, Evaluation of the degree of carbonation of concretes in three environments,

Construction and building Materials 230 (2020) 116804.

https://doi.org/10.1016/j.conbuildmat.2019.116804.

[23] Q. Zhou, F.P. Glasser, Thermal stability and decomposition mechanisms of ettringite at $<120{ }^{\circ} \mathrm{C}$, Cement and Concrete Research 31(2001) 1333-1339. https://doi.org/10.1016/S0008-8846(01)00558-0. [24] Q. Zhou, E.E. Lachowski, F.P. Glasser, Metaettringite, a decomposition product of ettringite, Cement and Concrete Research 34(2004) 703-710. https://doi.org/10.1016/j.cemconres.2003.10.027.

[25] L.G. Baquerizo, T. Matschei, K. Scrivener, Impact of water activity on the stability of ettringite, Cement and Concrete Research 79 (2016) 31-44. https://doi.org/10.1016/j.cemconres.2015.07.008. 
[26] T. De Larrard, F. Benboudjema, J.B. Colliat, J.M. Torrenti, F. Deleruyelle, Concrete calcium leaching at variable temperature: Experimental data and numerical model inverse identification, Computational Materials Science 49 (2010) 33-45. https://doi.org/10.1016/j.commatsci.2010.04.017. [27] I. Pane, W. Hansen, Investigation of blended cement hydration by isothermal calorimetry and thermal analysis, Cement and Concrete Research 35 (2005) 1155-1164.

https://doi.org/10.1016/j.cemconres.2004.10.027.

[28] J.I. Bhatty, Hydration versus strength in a portland cement developed from domestic mineral wastes - a comparative study, Thermochim Acta 106 (1986) 93-103. https://doi.org/10.1016/00406031(86)85120-6.

[29] V. Baroghel-Bouny, Water vapour sorption experiments on hardened cementitious materials: Part I: Essential tool for analysis of hydral behaviour and its relation to pore structure, Cement and Concrete Research 37(2007) 414-437. https://doi.org/10.1016/j.cemconres.2006.11.019.

[30] W. Taylor, Cement chemistry. Academic Press, London, 1997.

[31] R. Taylor, I. Richardson, R. Brydson, Composition and microstructure of 20-year-old ordinary Portland cement-ground granulated blast-furnace slag blends containing 0 to $100 \%$ slag, Cement and Concrete Research 40 (2010) 971-983. https://doi.org/10.1016/j.cemconres.2010.02.012.

[32] M.A.S. Shamaa, S. Lavaud, L. Divet, G. Nahas, J.M. Torrenti, Influence of relative humidity on delayed ettringite formation, Cement and Concrete Composites 58 (2015) 14-22.

https://doi.org/10.1016/j.cemconcomp.2014.12.013.

[33] A. Pavoine, X. Brunetaud, L. Divet, The impact of cement parameters on Delayed Ettringite Formation, Cement and Concrete Composites 34 (2012) 521-528.

https://doi.org/10.1016/j.cemconcomp.2011.11.012. 


\section{Appendix}

XRD, TGA/DTA and NMR data are presented in table 3, table 4, table 5, figures 13 and 14.

Table 3: Partial parameters obtained from XRD, TDA and NMR. (-) values not obtained. (*) values of C/S ratio is set to 1.5 to make possible the calculations of lime.

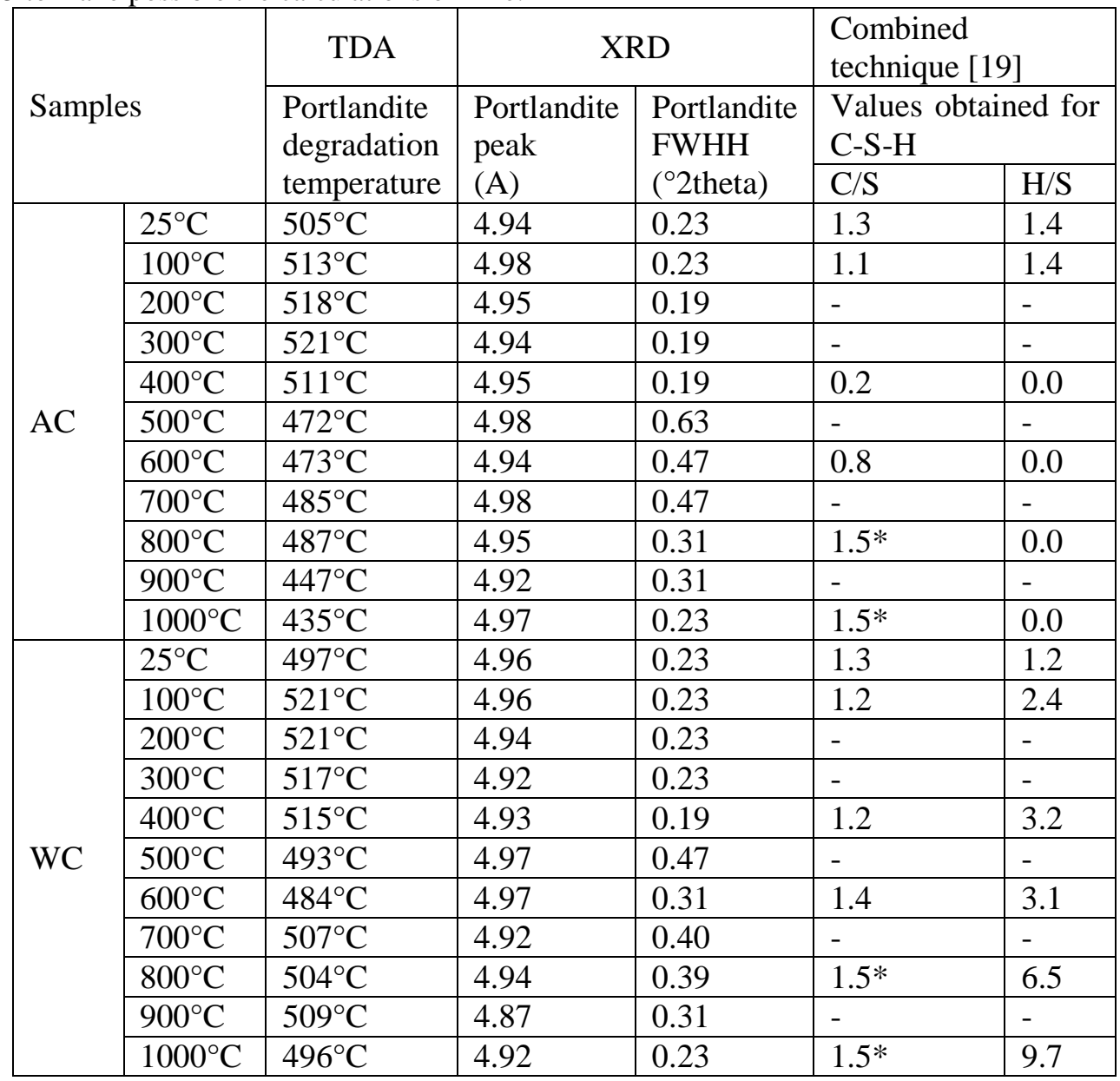


Table 4: Partial parameters of ${ }^{27}$ Al MAS NMR spectra deconvolution. Details of parameters and their meaning can be found in [18].

\begin{tabular}{|c|c|c|c|c|c|c|c|c|c|}
\hline \multirow{3}{*}{\multicolumn{2}{|c|}{ Samples }} & \multirow{2}{*}{\multicolumn{2}{|c|}{$\begin{array}{l}\mathrm{AFt} \\
(\mathrm{Xg}=0)\end{array}$}} & \multirow{2}{*}{\multicolumn{2}{|c|}{$\begin{array}{l}\text { AFm } \quad(\mathrm{Cz} \\
\mathrm{FWHH}=2.2 ; \mathrm{d}=5)\end{array}$}} & \multirow{2}{*}{\multicolumn{2}{|c|}{$\begin{array}{l}\text { TAH } \quad(\mathrm{Cz} \\
\text { FWHH=2.2; }=5)\end{array}$}} & \multirow{2}{*}{\multicolumn{2}{|c|}{$\begin{array}{l}\mathrm{Al}(\mathrm{IV}) \text { anh or } \mathrm{C}_{3} \mathrm{~A} \\
(\mathrm{Xg}=1)\end{array}$}} \\
\hline & & & & & & & & & \\
\hline & & \multirow{2}{*}{$\begin{array}{l}\begin{array}{l}\text { Position } \\
(\mathrm{ppm})\end{array} \\
13.3\end{array}$} & \multirow{2}{*}{$\begin{array}{l}\begin{array}{l}\text { FWHH } \\
(\mathrm{ppm})\end{array} \\
2.8\end{array}$} & \multirow{2}{*}{$\begin{array}{l}\begin{array}{l}\text { Position } \\
(\mathrm{ppm})\end{array} \\
10.7\end{array}$} & $\begin{array}{l}\text { EmAu / } \\
\text { nuQ }\end{array}$ & \multirow{2}{*}{$\begin{array}{l}\begin{array}{l}\text { Position } \\
(\mathrm{ppm})\end{array} \\
6.5\end{array}$} & $\begin{array}{l}\text { EmAu } \\
\text { and nuQ }\end{array}$ & \multirow{2}{*}{$\begin{array}{l}\text { Position } \\
(\mathrm{ppm})\end{array}$} & \multirow{2}{*}{$\begin{array}{l}\begin{array}{l}\text { FWHH } \\
(\mathrm{ppm})\end{array} \\
-\end{array}$} \\
\hline \multirow{11}{*}{$\mathrm{AC}$} & $25^{\circ} \mathrm{C}$ & & & & $\begin{array}{ll}700 \quad / \\
370\end{array}$ & & $\begin{array}{l}100 \quad / \\
600\end{array}$ & & \\
\hline & $100^{\circ} \mathrm{C}$ & 13.3 & 4.0 & 10.7 & $\begin{array}{ll}700 & / \\
370 & \end{array}$ & 6.7 & $\begin{array}{ll}100 & / \\
600 & \end{array}$ & - & - \\
\hline & $200^{\circ} \mathrm{C}$ & 13.3 & 4.0 & 10.7 & $\begin{array}{ll}700 & / \\
390\end{array}$ & 6.7 & $\begin{array}{ll}100 \\
600\end{array}$ & - & - \\
\hline & $300^{\circ} \mathrm{C}$ & 13.3 & 4.0 & 10.7 & $\begin{array}{l}800 \quad / \\
390\end{array}$ & 6.7 & $\begin{array}{l}100 \quad / \\
600\end{array}$ & - & - \\
\hline & $400^{\circ} \mathrm{C}$ & 13.3 & 4.0 & 10.7 & $\begin{array}{ll}800 \quad / \\
390\end{array}$ & 6.7 & $\begin{array}{l}100 \quad / \\
600\end{array}$ & 78.8 & 17.9 \\
\hline & $500^{\circ} \mathrm{C}$ & 13.3 & 4.0 & 10.7 & $\begin{array}{ll}800 \quad / \\
390\end{array}$ & 6.7 & $\begin{array}{l}100 \quad / \\
600\end{array}$ & 78.8 & 17.9 \\
\hline & $600^{\circ} \mathrm{C}$ & 13.3 & 4.0 & 10.7 & $\begin{array}{ll}800 & / \\
390 & \end{array}$ & 6.7 & $\begin{array}{ll}100 \\
600\end{array}$ & 78.8 & 17.9 \\
\hline & $700^{\circ} \mathrm{C}$ & 13.5 & 3.0 & 11.1 & $\begin{array}{ll}700 \quad / \\
320\end{array}$ & 6.7 & $\begin{array}{l}100 \quad / \\
600\end{array}$ & 78.8 & 17.9 \\
\hline & $800^{\circ} \mathrm{C}$ & 13.3 & 3.0 & 11.3 & $\begin{array}{l}700 \quad / \\
320\end{array}$ & 6.7 & $\begin{array}{l}100 \quad / \\
600\end{array}$ & 78.8 & 17.9 \\
\hline & $900^{\circ} \mathrm{C}$ & 13.3 & 3.0 & 11.3 & $\begin{array}{l}700 \quad / \\
320\end{array}$ & 6.7 & $\begin{array}{ll}100 & / \\
600\end{array}$ & 78.8 & 17.9 \\
\hline & $1000^{\circ} \mathrm{C}$ & 13.5 & 3.2 & 11.1 & $\begin{array}{ll}700 & / \\
320 & \\
\end{array}$ & 6.7 & $\begin{array}{ll}100 & / \\
600 & \\
\end{array}$ & 78.8 & 17.9 \\
\hline \multirow{11}{*}{ WC } & $25^{\circ} \mathrm{C}$ & 13.3 & 2.8 & 10.7 & $\begin{array}{ll}700 \quad / \\
370\end{array}$ & 6.5 & $\begin{array}{l}100 \quad / \\
600\end{array}$ & - & - \\
\hline & $100^{\circ} \mathrm{C}$ & 13.5 & 3.0 & 10.9 & $\begin{array}{l}700 \\
1370\end{array}$ & 6.7 & $\begin{array}{l}100 \quad / \\
600\end{array}$ & - & - \\
\hline & $200^{\circ} \mathrm{C}$ & 13.3 & 4.0 & 11.3 & $\begin{array}{l}700 \quad / \\
390\end{array}$ & 6.7 & $\begin{array}{l}100 \quad / \\
600\end{array}$ & - & - \\
\hline & $300^{\circ} \mathrm{C}$ & 13.5 & 3.0 & 11.3 & $\begin{array}{l}700 \quad / \\
410\end{array}$ & 6.7 & $\begin{array}{l}100 \quad / \\
600\end{array}$ & - & - \\
\hline & $400^{\circ} \mathrm{C}$ & 13.3 & 4.0 & 11.3 & $\begin{array}{l}700 \\
410\end{array}$ & 6.7 & $\begin{array}{ll}100 \\
600\end{array}$ & 78.8 & 15.0 \\
\hline & $500^{\circ} \mathrm{C}$ & 13.5 & 3.2 & 11.3 & $\begin{array}{ll}650 & / \\
350\end{array}$ & 6.7 & $\begin{array}{l}100 \\
600\end{array}$ & 78.8 & 17.9 \\
\hline & $600^{\circ} \mathrm{C}$ & 13.5 & 3.2 & 11.5 & $\begin{array}{ll}650 & / \\
320 & \\
\end{array}$ & 6.7 & $\begin{array}{ll}100 \\
600\end{array}$ & 78.8 & 17.9 \\
\hline & $700^{\circ} \mathrm{C}$ & 13.3 & 4.0 & 11.3 & $\begin{array}{ll}650 \\
320\end{array}$ & 6.7 & $\begin{array}{l}100 \quad / \\
600\end{array}$ & 82.0 & 17.9 \\
\hline & $800^{\circ} \mathrm{C}$ & 13.5 & 3.0 & 11.3 & $\begin{array}{ll}650 & / \\
320\end{array}$ & 6.7 & $\begin{array}{l}100 \\
600\end{array}$ & 82.0 & 17.9 \\
\hline & $900^{\circ} \mathrm{C}$ & 13.2 & 3.3 & 11.3 & $\begin{array}{ll}650 & / \\
350 & \end{array}$ & 6.7 & $\begin{array}{ll}100 \\
600\end{array}$ & 82.0 & 17.9 \\
\hline & $1000^{\circ} \mathrm{C}$ & 13.6 & 3.0 & 11.0 & $\begin{array}{ll}650 & / \\
350\end{array}$ & 6.7 & $\begin{array}{ll}100 & / \\
600 & \end{array}$ & 82.0 & 17.9 \\
\hline
\end{tabular}


Table 5 : Partial parameters of ${ }^{29}$ Si MAS NMR spectra deconvolution. Details of parameters and their meaning can be found in [18].

\begin{tabular}{|c|c|c|c|c|c|c|c|c|c|}
\hline \multirow{2}{*}{\multicolumn{2}{|c|}{ Samples }} & \multicolumn{2}{|l|}{$\mathrm{Q}^{0}\left(\mathrm{C}_{2} \mathrm{~S}\right)$} & \multicolumn{2}{|c|}{$\mathrm{Q}^{1}(\mathrm{C}-\mathrm{S}-\mathrm{H})$} & \multicolumn{2}{|c|}{$\mathrm{Q}_{\mathrm{P}}^{2}(\mathrm{C}-\mathrm{S}-\mathrm{H})$} & \multicolumn{2}{|c|}{$\mathrm{Q}_{\mathrm{NP}}^{2}(\mathrm{C}-\mathrm{S}-\mathrm{H})$} \\
\hline & & \multirow{2}{*}{$\begin{array}{l}\begin{array}{l}\text { Position } \\
(\mathrm{ppm})\end{array} \\
-71.4\end{array}$} & \multirow{2}{*}{$\begin{array}{l}\begin{array}{l}\text { FWHM } \\
(\mathrm{ppm})\end{array} \\
1.7\end{array}$} & \multirow{2}{*}{$\begin{array}{l}\text { Position } \\
(\mathrm{ppm}) \\
-79.0\end{array}$} & \multirow{2}{*}{$\begin{array}{l}\text { FWHM } \\
(\mathrm{ppm}) \\
3.4\end{array}$} & \multirow{2}{*}{$\begin{array}{l}\text { Position } \\
(\mathrm{ppm})\end{array}$} & \multirow{2}{*}{$\begin{array}{l}\text { FWHM } \\
(\mathrm{ppm})\end{array}$} & \multirow{2}{*}{$\begin{array}{l}\text { Position } \\
(\mathrm{ppm})\end{array}$} & \multirow{2}{*}{$\begin{array}{l}\text { FWHM } \\
(\mathrm{ppm}) \\
3.5\end{array}$} \\
\hline \multirow{6}{*}{$\mathrm{AC}$} & $25^{\circ} \mathrm{C}$ & & & & & & & & \\
\hline & $100^{\circ} \mathrm{C}$ & -71.3 & 1.7 & -78.9 & 4.0 & -81.3 & 3.8 & -84.9 & 4.0 \\
\hline & $400^{\circ} \mathrm{C}$ & -71.2 & 1.5 & -78.8 & 4.3 & -81.7 & 3.8 & -85.3 & 3.2 \\
\hline & $600^{\circ} \mathrm{C}$ & -71.4 & 1.5 & -78.8 & 4.3 & -81.7 & 3.8 & -85.3 & 3.2 \\
\hline & $800^{\circ} \mathrm{C}$ & -71.2 & 1.8 & -78.8 & 4.3 & -81.7 & 3.8 & -85.3 & 3.2 \\
\hline & $1000^{\circ} \mathrm{C}$ & -71.3 & 1.2 & -78.8 & 4.3 & -81.7 & 3.8 & -85.3 & 3.2 \\
\hline \multirow{6}{*}{ WC } & $25^{\circ} \mathrm{C}$ & -71.4 & 1.7 & -79.0 & 3.0 & -81.3 & 3.5 & -84.9 & 3.2 \\
\hline & $100^{\circ} \mathrm{C}$ & -71.2 & 1.5 & -78.8 & 4.3 & -81.7 & 3.8 & -85.3 & 3.2 \\
\hline & $400^{\circ} \mathrm{C}$ & -71.2 & 1.5 & -78.8 & 4.3 & -81.7 & 3.8 & -85.3 & 3.2 \\
\hline & $600^{\circ} \mathrm{C}$ & -71.3 & 1.5 & -78.8 & 4.3 & -81.7 & 3.8 & -85.3 & 3.2 \\
\hline & $800^{\circ} \mathrm{C}$ & -71.2 & 1.2 & -78.8 & 4.3 & -81.7 & 3.8 & -85.3 & 3.2 \\
\hline & $1000^{\circ} \mathrm{C}$ & -71.3 & 1.2 & -78.8 & 4.3 & -81.7 & 3.8 & -85.3 & 3.2 \\
\hline
\end{tabular}
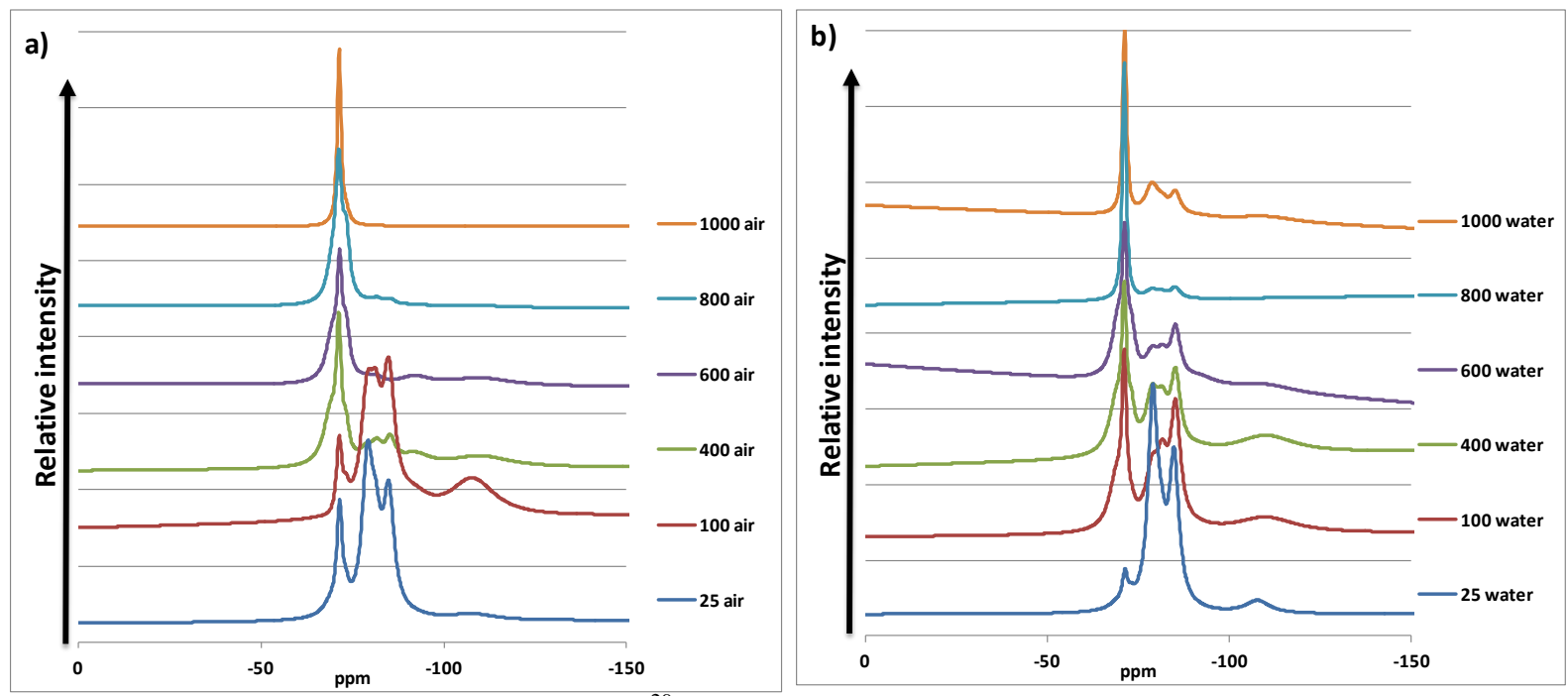

Figure 13: Comparison of spectra obtained by ${ }^{29} \mathrm{Si}$ NMR. The cement pastes are exposed to various temperature and the same cooling regime (air or water). 

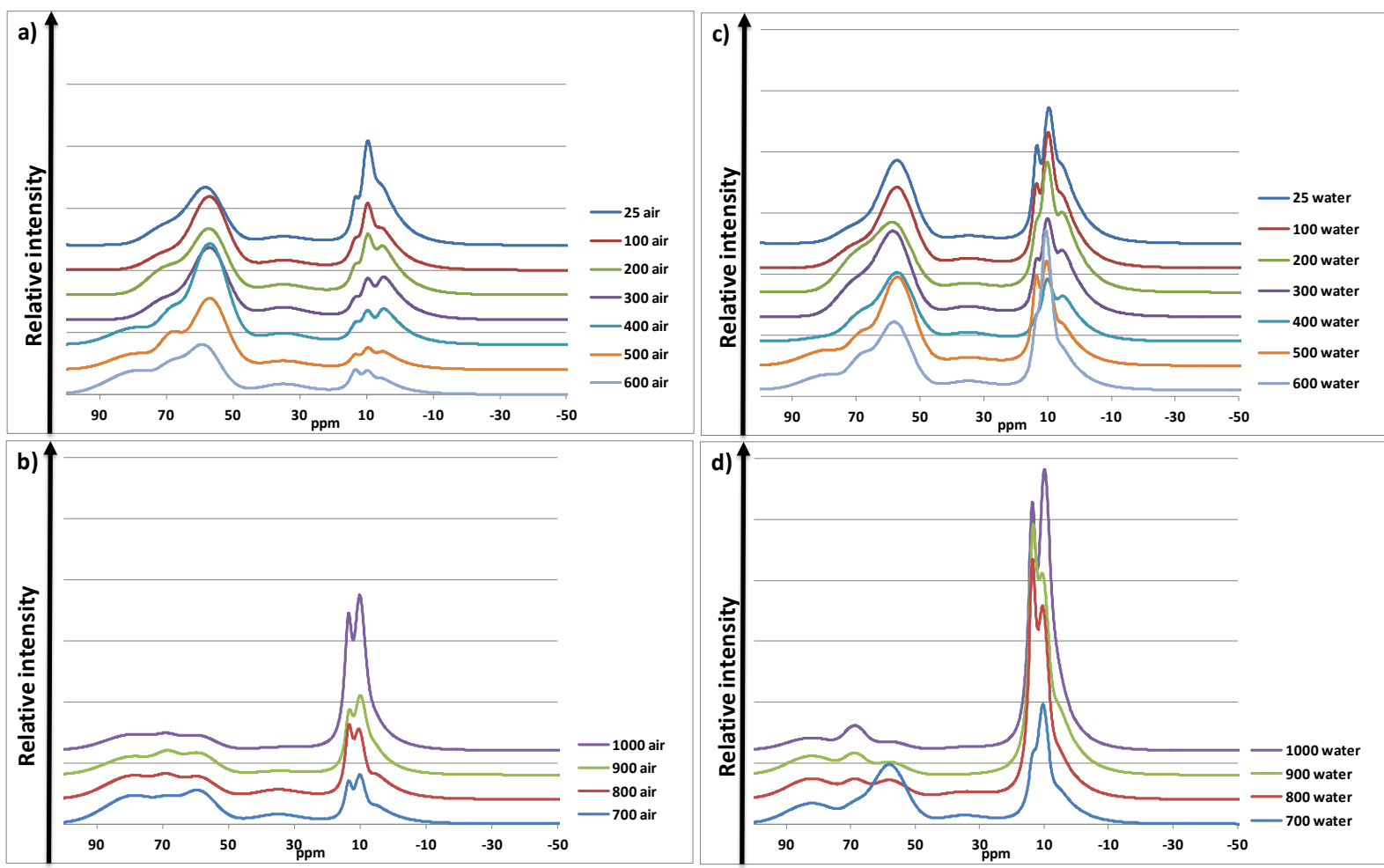

Figure 14: Comparison of spectra obtained by ${ }^{27} \mathrm{Al}$ NMR. The cement pastes are exposed to various temperature and the same cooling regime (air or water). 